\title{
STUDIES ON VASCULAR PERMEABILITY AND MUCOSAL ABSORPTION IN THE FIELD OF OTO-RHINOLOGY
}

\author{
Part I Systemic Vascular permeability \\ Y. TOGANOW, M. D. \\ From the Department of Oto-Rhino-Laryngology, Tokyo Medical College \\ (Director: Prof. Toshio Shiraiwa)
}

The author studied vascular permeability in healthy subjects and in those with various diseases accompanied with spontaneous nasal bleeding, using Landis' method. The Capillary Permeability Promoting Factor of Menkin was also studied at the same time. Results obtained were as follows:

1) C.P.P factor level was variable even in healthy subjects.

2) Vascular permeability for protein was far less variable compared with that for fluid.

3) There was no direct relationship between vascular permeability and bleeding. Vascular perme. ability and vascular fragility were the characteristics not related each other.

4) Vascular permeability for fluid was remarkably increased in those with spontaneous nasal bleeding and allergy. Vascular fragility was also increased in many cases.

5) Vascular permeability and C.P.P factor were within normal limits even in the cases with leucemia and purpura in which bleeding tendency was prominent. Capillary fragility in these cases was remarkably increased.

6) In cases with chronic sinusitis, fluid permeability was increased in many instances. After the surgery for sinusitis, C.P.P factor was elevated and fluid permeability was further increased.

There was no change in C.P.P factor level in cases with simple hemorrhage and blood loss.

7) Bleeding tendency observed clinically was related to fragility of the capillaries.

\section{耳鼻科領域における脈管透過性及び粘膜吸収性に関する研究}

\section{第 1 篇 全身的透過性飞就いて}

東京医科大学耳鼻咽喉科教室（主任：白岩俊焳教授）

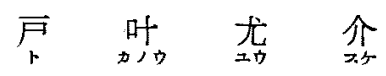

内容目次

\section{1 緒言}

1 文献的考察

1) 透過と吸收の系路

2）血液成分の透過

3）蛋白の透過炕就いて

4）蛋白透渦量の測定に関して

5) 透過汇関倸する諸因子

田実験方法

A. 臨床実験
1）邀過性の㛟查

2） C. P.P 因子の测定

3）皮腸及び粘膜澄血斑的测定

4）その他の血夜因子

B. 動物実蛤

1）透過と温血心場汇関する観察

2）鬼鼻中隔粘獏への色素透遇の観察

IV 実験対象

$V$ 実駼成縜

A. 臨床检查成續 
1)践康者に就いて

2) 舞及び咽頭出血虫著に就いて

3) 血液病患者に就いて

4) アレルキ゚ー体質者に就いてて

5） i 副盘腔炎患者に就いて ii 副率腔手術の影㮣

6)失血と C. P. P. 因子量に就いて

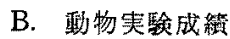

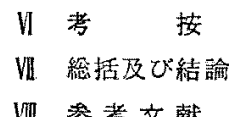

VII 参考文献

\section{I 緒 言}

血管の透過性とは，血液成分が血管壁学通逗して血管

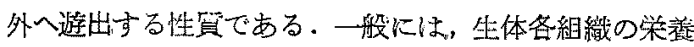
を司るために，毛細管壁を物筫が通過し交換される現变 をいらので，広議では赤血琲や白血球の通過も含まれ る.

1908 年の Starling の郝告では，純物理化学的な翏

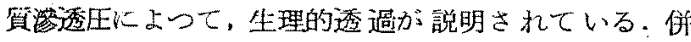
し，この時代にはこの力面の研究は未垎图であつた。 即ち，古興医学では不可視・不可触の透過の状態を直接 に把接する手段に久けていたし，透過性の六進を思わせ

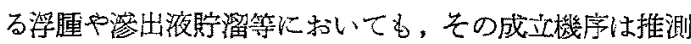
の域を出なからた，又，局所の吸収性との関係も不明で

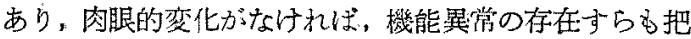
搌できなかかた。

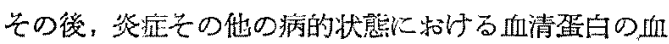

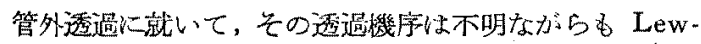
is (1927) は炎府局所の血管透蛊を起可子の上してH物

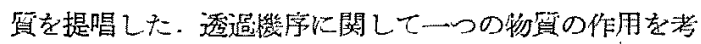
点たといら点では畋期的な意見であるか゚，艺の本体は明 らかにしていない。

1940 年に Menkin は, 炎症性荟出液加血管透遗性 を穴進ざる物筫を分離しようとして，遂い白血球走

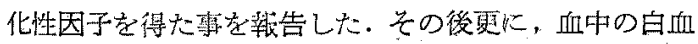

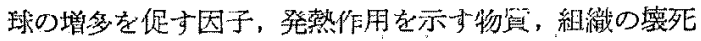

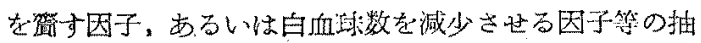

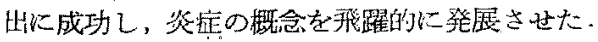

この後，この方面の研究は䫏に盛えになり，本邦に等 いても注目子べき研究が相次いで発表されるに到つだ。 このよらにして透邀性の機序は次第に解明されてきた。

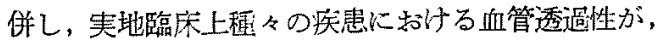

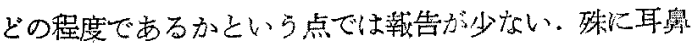

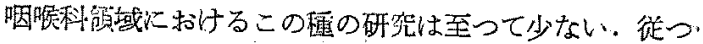
て，血管透遗性の問題は臨床庭状に密度な関保を有方る にも拘らず，末解沠の分些なのである。

文，脈管の吸収性に関しても，従前は適当な研究方法。

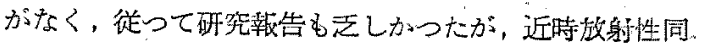
位元糸が医学的に tracer として利用されるに到つて， 始めて直接的な観察が可能となり，透過性と共にこの方。

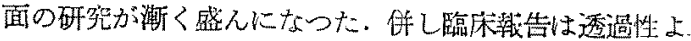
り更更纪しい。

このよらな理由で著者は，吸收性に関する研究では，

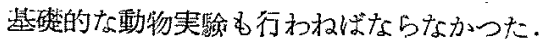

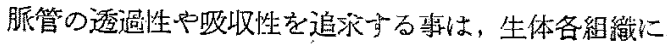
おける物貿交採を理解与るためにも，血球の活動の場と

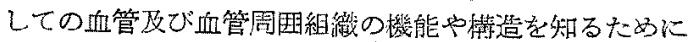
も一つの重要な指䅺となる. 又単に同所症状の解明に留。 まらず，現在なで推察の域を脱し得なかつた同所症状と 全身状態との閦俰を理解寸るなめにる，有力な手段とな 志。

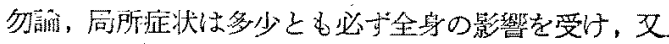

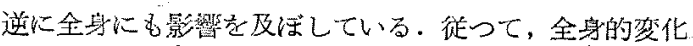

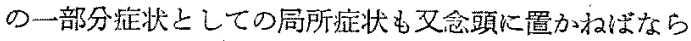

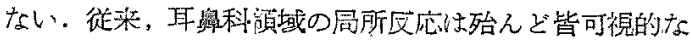
形態変化を伴つていた。併し，機能という観点からは

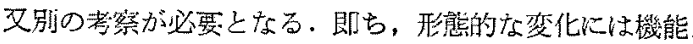
的な变化が先行するであらうし，機能的变化化は全射状 態のいかんが条件とたるからである。この上らに同所子 全身恮く不可分のものである。

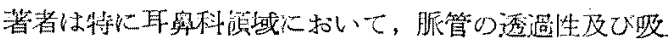

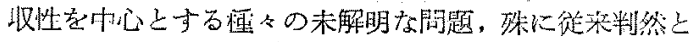

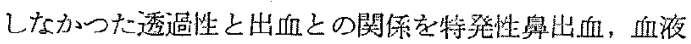

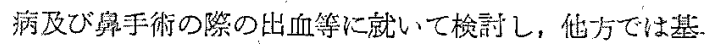
碟的にも程々の勘物実駼を行つて研觉してみた。

\section{II 文献的考察}

1) 透過七樶収の系路

人体の同所变化は年の局所の体液循畹の暴常によつて

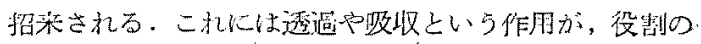

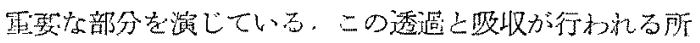

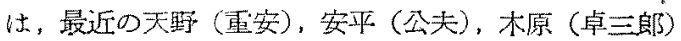

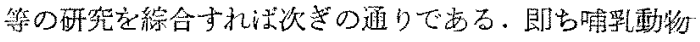
では脈管機構に閉鎖性血管采と閉鎖性淋巴采とがすり, 生理的透避生主として細静脈方ら行われ，一部は細静脈 わら再吸收され，大部分は脈管外通渡路系を経て，洣巴． 彩吸収されるといら (本原)。 
又，天野の実駼によれば，動物が病的の透邀性を示す 場合，物資の程類によって透過する場所が異る事を発見 している.

即台，血球，墨汁，蛋白等は細静脈加ら透過し，各画 の色素のような微粒子小毛細管から透逜する。乙か子色 莱の程漬いかんで,分肢毛細管,網状毛細管及び集合毛細 管などのらち、それぞれ特買の場所から透過するといら．

2）血液成分の透遗

血液の液体成分に就いては，并の組成中最子透過乙易 いと考学られる水，及びこれ《溶解している物貿と，最 毛粒子の大きい胥白留とは，自ら艺の透過，败收の態度 を異にするものと想像される，従って，それ等の量的関 保にも差があるう。

Küchmeister に上礼ば，血管の透過性には，液体透 過性と蛋白透過性及び毛細管壁の赤血球透過性（出血） 等が区別されるという，彼等の研究によると，液体透過 性と蛋白透恧性との問に性相関関保を認めるが，赤血球 の透過性とは一致しないという，例え注，真性高血圧患 者の 20\%には毛細血管の脆弱性を証明できるが，透過 性の㭘查では正常の所見を得た。即ち，水や蛋白の透過 性が正常であるので孚腫等を起さずに，いきなり脳出血 が起るのであるという，著者の研究成績にも，同椂の事 が血液病患者で事㥶として見它机ている。

3）蛋白の透通炕就いて

Starling (1908) の膠筫渗透压といら考光から出た生 理的透邀性は，血管壁の蛋白不透過を条件としている。 その後永くこの考えは修正されなからた。

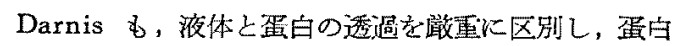
の透過は小血管壁の性状の異常化が原因となるといら。

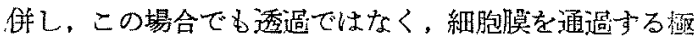

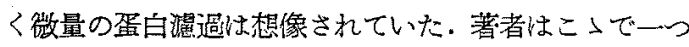

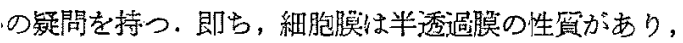
蛋白の濾逼が行われても不思義でない，併し，更に大 きな粒子の色素や墨汁を透過させる血管間隌から，蛋白 が通過しないという䎼は沏かしい，併し，天野は生理的

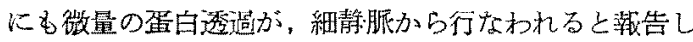
た。

更汇病的状態上生理的状態とは，䟧然と区別できるも のではない，両者の間には必ず移行状態がある，透過性 ルたけ二つの状態加確然と分れているという考光も招か LW.

4）蛋白透遌量の測定に就いて

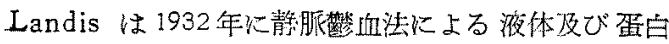

の透過量測定法を発表した。即ち，上椸を圧迫して生ず る籍血の際の液体成分乃至蛋白成分の血管外晩出を，时 部静脈血の変化から算定するのである。上腕は比較的簡 単な構造をしていて，病変の及び難い部分であり，多少 の異解はあるらが先づこの部の透過性を以て，全身の透 過性を代表するものとしても然理が少ないと考光る。

但し，この透過性は先人及ひ著者の実験から推して， 毛細管の透遄性ではない，従って Menkin の毛䋖血管 透過性光進因子 Capillary permeability promoting factor（以下，C. P. P. 因子々略す）の量とは，必ず しも平行しないだうっここの点も著者江追究した。

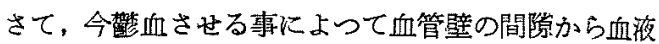
の液件成分だけが透過したと仮定する，先の結果血管内 の血液は垬縮されて，Hematocrit 值は上昇し，同様に 血清蛋白量も增拁する. 若しこつで蛋白の透過も同時代 起つたとすれば，蛋白の透過が小である程血管内の血清

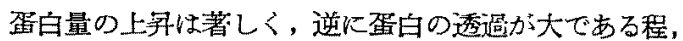
血清蛋白量の上荊は少ない，即ち，Landis 法による実 験值を眺める時, Hematocrit 值の变動と平行する液体 透過性に対して，蛋白透過性は全く逆の観方をしなけれ ばならない，換言すれば，血清蛋白量の変動が大きい 程，蛋白透蛊度は小さいのである，乙か子相互に不可分 の関運がある。

Eppinger はこの測量值から液体透過量と蛋白透過量 を計算する関保式を示した．この式は，大まかで簡単な 原理に基ついて扣り，璉々の細かい条件には触れていな いこれに就いては考按の所で述べるが，これ等の条件 は実際の測定値に会り影響しないと思らので，著者はこ の式を利用して，透遄量計算の手段とした。

5）透過に関集する諸因子

Menkin の C. P. P. 因子は，毛細血管の透過性充進 に重要な役割を演ずるがこの他にも程々の因子が考え られる。

西丸 (和義) は, 1950 年血液学討議会報告心次の諸 条件を挙计た. 即ち，水力学的圧差，荟透王的効果，1 オンの作用，温度，水素イオン濃度，組織や血流化関す る檑々の楽㕮, 及ご溶貿の濃度差である。

これ等の画々の組合せが血管壁の条件之相侯つて透過 性を浃定していると考えて先つ愦りはあるまい，

\section{III実験方法}

A. 陪床椧查法

1) 透洞性の検查

被榆者を仰卧せしめ，血圧測定の時の上うに片側の上 
腕に水銀血生計の Manchette を巻き，水銀柱 $40 \mathrm{~mm}$ で30分間圧迫する.これは Landis の方法であるが

Darnis はの 80 85 mm Hg 圧力を用いている。しか しこの圧力は患者に苦痛を与える。

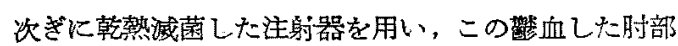
の静脈から静脈血約 $5 \mathrm{cc}$ を採取し，これを2本の偝驗 管に分注寸る。この中の1本には血液凝固阻止のたるに 予適量の二重苳酸か人机ておる。この試駼管の血液か ら Hematocrit 値を打藤氏の Hematocrit 管で，他から 任血清蛋白量を日立蛋白計で定量しだ，同時に他側の肘 部静脈加ら然圧迫のを〉血液 $5 \mathrm{cc}$ を採取し，同様の操 作で Hematocrit 值及び血清蛋白量を定量して比較対照 した.

2) Menkin の C. P. P. 因子测定

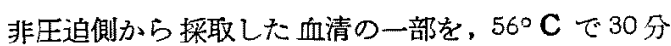
間加温して非働化し，室温に放置する，次にこの血清の 稀釈系列をつくる。この稀釉系列は研究者により一定で ない，著者はそれ等を参考として，5，25，50，100，

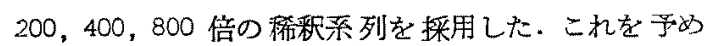

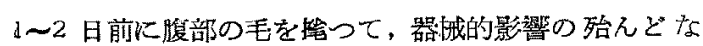

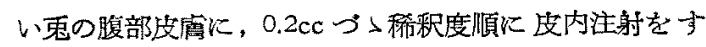
る. 次さ直ちに $37^{\circ} \mathrm{C} に$ 饬温した $1 \%$ Trypanblau生 理的食塩水溶液を，去の家鬼の耳静脈から注入し，䧗部 の稀釈血清の皮内注射局所に Trypanblau が沴出して くるか否かを，約 15 分観察した．対照として同部位に 並んた所へは，生理的食塩水を同じく没内注射して置い ホ.このよらにして何倍济釈血清の皮内注射部位にま で，色美が出してくるが検行してみた。

3）皮掌及び粘膜溢血斑

蛋白の透過は血管壁の性状の玟化を条件上京るといら Darnis の説がある。これに問題がある事は既述の通り である.今参考のために血管の抵抗性の指標として，院 王法による溢血斑数，及び本教室の井上に上る粘脱の溢

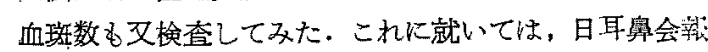

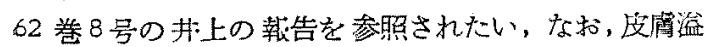
血斑は Landis 法が肘部静脈血を用いる事と関逋して,

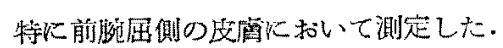

4) その訨の出血因子

その他, 赤血球数, 白血恄数, 血小板数, 出血時間, 懝固時間，プロトロンビン時間，Ca 再浙凝固時間， 人 モグロビン量, 及び本教室米上の稢莫出血時間等も椧查 して透過性と刘比した。これ等に就いては項を改め一括 そて記述する。

\section{B. 動物実駼}

1) 透邀生と溢血斑の場に就いての実験

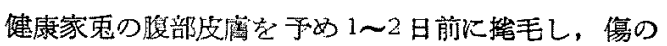

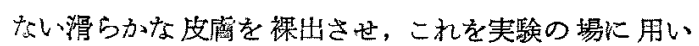
る。この象を何卧位に固定し，耳静脈に 1\% Trypanblau 生食水溶液学注射する, 次に小漏斗を用い, 人間の場合

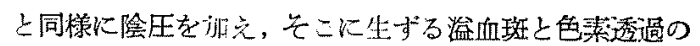
場を観察した，

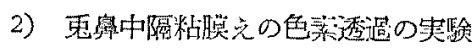

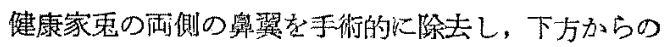
透過光線で䡛微鏡下に鼠中隔を钼察する。毛細血管之細 動，散脈の血球の移動方向が異なる場所を視野に出し， 観察を続けながら，助于に命じて Trypanblau 溶液を 呌静脈から徐々に注射せしめ，視野に出現するこの色素 の状洗を覵察する。

\section{IV 実験対象}

1、促康者として, 束京医大病院の医師, 看護婦及ず 職員 12 名.

2. 本院耳利を訪机た鼻出血及び咽頭出血患者22名.

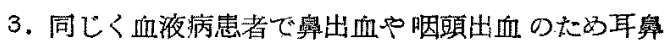
科の治潦を依賴されたもの14名。

4. 同しく遄去又は現在代著明なアレルギー性疾患を 有するアレルギー体貿者15名.

5. 同じく慢性副鼻膑炎患者 15 名.

6. 本院血液銀行を訪れた膱業的供血者 13 名. 管。これらは任賞に抽出されたものである。

\section{$\mathbf{V}$ 実験成樍}

A. 臨床検查成椯
表 1

\section{健康人的血管透過性}

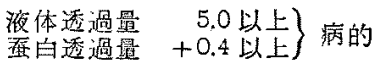

血讳蛋白是正常值 $6.5 \sim 8.0 \%$ ヘ习トソツト正常值 $\left\{\begin{array}{l}\text { 男 } 39-52 \\ 女 \text { 女 } 35-48\end{array}\right.$

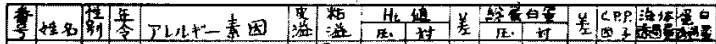

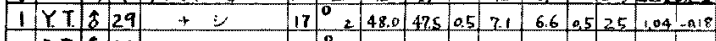

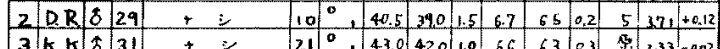

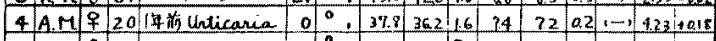

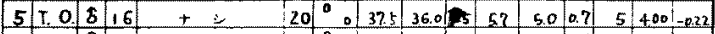

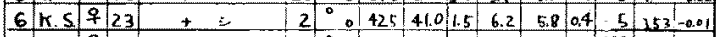
7 T. $920+22^{\circ}, 4003450.5-6.6-400.23-$

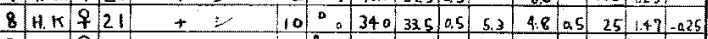

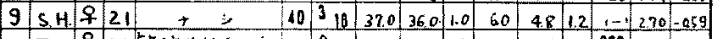

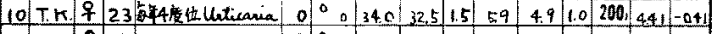

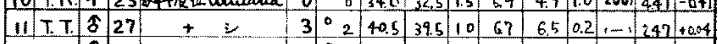

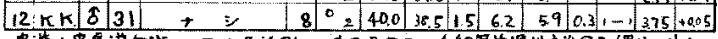

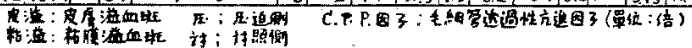


1) 健康者に就いて

表1は自覚昰状なく，本院て健康に偅いている者の 血管透過性の检查成績である。

後述の実験で，透迵性がフレルギーと関保が樑とうな

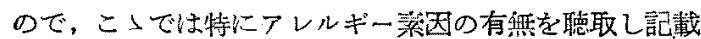
した。

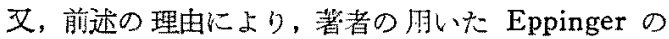
式を次に示す。

i 液体透遗量X：100 cc の血液からの选過した量 cc

$$
\mathrm{X}=100-100 \frac{\mathrm{Hu}}{\mathrm{Hg}}
$$

Hu：対照側の Hematocrit 值

$\mathrm{Hg}$ ：生迫側の Hematocrit 值

ii 蛋白透過量 $\overline{\Delta \mathrm{Pr}}$ ： $1 \mathrm{cc}$ の血液方ら出た量 gr.

$$
\overline{\Delta \operatorname{Pr}}=\operatorname{Pr}_{1} \frac{\mathrm{PI}_{1}}{100}-\operatorname{Pr}_{2} \frac{\mathrm{PI}_{1}-\mathrm{X}}{100}
$$

$\mathrm{Pr}_{1}$ ：対照倒の血清蛋白量（血清 $100 \approx \mathrm{c}$ 中の量gr/d1）

$\mathrm{Pr}_{2}$ ：生运侧の血清蛋白量

$\mathrm{PI}_{1}$ ：対眼側の血清量（全血に刘寸る血清の容稏百 分比，従つて $100-\mathrm{Hu}$ でする。)

iii 更にこの蛋白透過量の液体透遇量に゙対する百分比

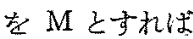

$$
\mathrm{M}=100 \frac{\overline{\Delta \mathrm{Pr}}}{\mathrm{X}}
$$

である。著者は，X 值及び $\overline{\Delta \mathrm{Pr}}$ 值を採用した。この 式によつて計算した数值を表 Iで見ると，液体透過量は 悉〈正の符号を有するが，蛋白透過量では，11 例中 7 例子負号を有寸る，絶対值は甚だ小である。これに就い ては考按に赫いて詳しく揃ずる。

著者は，この先験值及び他の研究者の街告を考考亡し

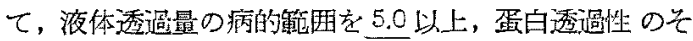

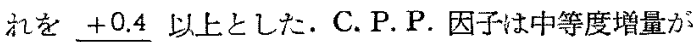

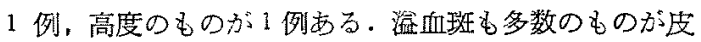

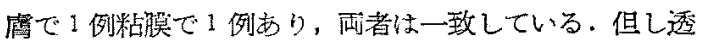

\begin{tabular}{|c|c|c|c|c|c|}
\hline \multirow[b]{2}{*}{ 姓名 } & \multirow[b]{2}{*}{ 性 } & \multirow[b]{2}{*}{ 年令 } & \multirow[b]{2}{*}{ 疾病 } & \multicolumn{2}{|c|}{ C.P.P. 因子 } \\
\hline & & & & 1 回目 & $20 \theta_{(\dot{x})}$ \\
\hline YT. & $\hat{o}$ & 29 & 健康 & 125 & 25 \\
\hline M.I. & $\hat{o}$ & 44 & $\begin{array}{c}\text { 且咽晩 } \\
\text { 出 血 }\end{array}$ & 125 & 原 \\
\hline N.I. & 우 & 13 & 白血病 & 险性 & 5 \\
\hline T.K. & 우 & 22 & 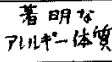 & 25 & .200 \\
\hline
\end{tabular}

表 2

同一人に於けるC.P.P. 因子量の变敦
過量との関保はない。

C. P.P. 因子を約半カ年の期間を䈯いて調へた成樍が

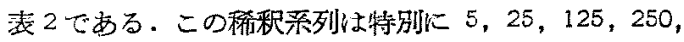
といら系列を使用した，表 1 と併せて C. P. P. 因子が

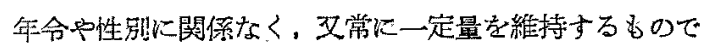
はない事がわかる、なお，表 2 の最後の例子，春秋に必

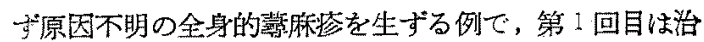

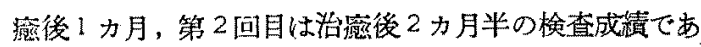
b.

2）番出血及び啁頭出血蚛者に就いて

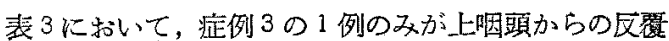

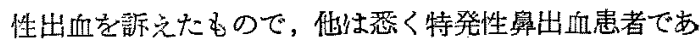

\begin{tabular}{|c|c|c|c|c|c|c|c|c|c|c|c|c|c|}
\hline 䲞 & 急 & & \begin{tabular}{|l} 
霍 \\
潼
\end{tabular} & $\begin{array}{l}\text { 籸 } \\
\text { 淈 }\end{array}$ & $\frac{H}{E}$ & it & $\frac{1}{1}$ & tit & at & $\frac{8}{8}$ & $\left\{\begin{array}{l}\text { CRP } \\
\text { 由 }\end{array}\right.$ & 13 & 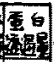 \\
\hline $1 \%$ & & 6 & 2 & & 40.2 & 37.8 & 2.4 & & 67 & 0.4 & $25<$ & 5.97 & \\
\hline 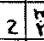 & 9 & 22 & 62 & 1 & 41.0 & 38,2 & 28 & 6.8 & 6.6 & 0.2 & 258 & 6.85 & \\
\hline 3 & $\begin{array}{l}4 \\
i\end{array}$ & 44 & 無数 & 22 & 390 & 36.0 & 3.0 & 52 & 4.4 & 0.8 & 125 & 3.69 & \\
\hline 5 & 58 & 62 & 0 & ${ }^{\circ} 5$ & $40 . \mathrm{c}$ & 39.2 & 1.4 & & 55 & 2.8 & $\therefore-1$ & 3.45 & \\
\hline $5 \mathrm{z}$ & $\begin{array}{c}0 \\
\sim\end{array}$ & 32 & 32 & $2_{3}$ & 290 & 28.0 & 1.0 & 9.6 & 7.0 & 2.6 & 125 & 3.45 & \\
\hline $6 !$ & $\begin{array}{l}0 \hat{5} \\
5\end{array}$ & 19 & 32 & $0_{2}$ & 43.0 & 42.0 & 1.0 & 7.8 & 7.4 & 0.4 & 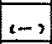 & 23 & \\
\hline 7 & $\hat{\theta}$ & 25 & 36 & ${ }_{20}^{3}$ & 43.5 & 42.0 & 1.5 & 8.1 & 7.0 & 1.1 & 125 & 344 & \\
\hline & 5 & 52 & 23 & ${ }^{\circ} 13$ & 30.3 & 22.8 & 7.5 & 8.1 & 5.9 & 2.2 & 625 & 24.75 & \\
\hline 95 & $\begin{array}{l}5 \\
4\end{array}$ & 53 & 0 & $D_{2}$ & 28.5 & 28.2 & 0.3 & $6 ?$ & 6.3 & 0.4 & $(-)$ & 105 & $4+93$ \\
\hline & to & 54 & 7 & 17 & 325 & 35.0 & 45 & 74 & 2.0 & 0.4 & 5 & 11.39 & +0.5 \\
\hline & 19 & 45 & 24 & $0_{4}$ & 39.0 & 35.2 & 13.8 & 8.0 & 7.5 & 0.5 & 800 & 9.15 & +014 \\
\hline & 5 & 39 & 46 & $2-1$ & 440 & 43.0 & 1.0 & 7.5 & 7.2 & 0.3 & 原 & $22^{\prime}$ & \\
\hline $13[i$ & î & 23 & 10 & $D_{3}$ & 490 & 40.0 & 9.0 & 6.0 & & 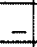 & 400 & 18.31 & \\
\hline 147 & 18 & 30 & 42 & 3.6 & 422 & 39.5 & & 68 & 64 & a4 & 400 & 6.39 & to. \\
\hline $155^{h}$ & $\delta$ & 58 & 3 & $0^{\circ}$ & 24.2 & 24.0 & 0.2 & 6.2 & 5.8 & a. & 200 & 0.8 & \\
\hline $16 ?$ & $\begin{array}{l}i s \\
i\end{array}$ & 17 & $=$ & $1=$ & 40.1 & 38.7 & 1.4 & 7.2 & 5 & 1.8 & 点. & 34 & \\
\hline 17 & 48 & 33 & 47 & $66_{11}$ & 400 & 39.5 & 0,5 & 7.2 & 6.8 & a. & 200 & & \\
\hline 18 & s: & 21 & 15 & & & 325 & 0.5 & 6.6 & & a. & & & $+\infty$ \\
\hline 19 & is & 37 & 8 & $0^{\circ} 2$ & $4-a 2$ & 39.8 & 6.4 & 2.0 & 69 & 0.1 & 200 & & \\
\hline $20:$ & $\begin{array}{c}4 \\
t \\
y\end{array}$ & 53 & 18 & 8 & 425 & 47.2 & \begin{tabular}{|l}
0.3 \\
\end{tabular} & 6.9 & 68 & 0.1 & $(-)$ & ab & \\
\hline & $\begin{array}{ll}5 \\
\text { s. }\end{array}$ & 25 & 30 & ${ }_{4}^{\circ}$ & 27.5 & 26.5 & 1.0 & 6.4 & 6.2 & 0.2 & 400 & 1.81 & $\left(-20^{2}\right)$ \\
\hline$[22]$ & 8 & $5 \longdiv { 4 5 }$ & 15 & 53 & 294 & & 3 & 54 & & & 400 & & +0.6 \\
\hline
\end{tabular}

\section{表 3}

鼻出血及で咽頭出血患者の血管透過性

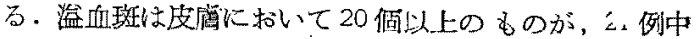

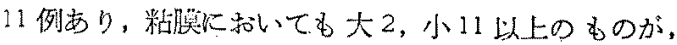
21 例中 10 例あり, 血管の脆弱性の存在思小世万。舟

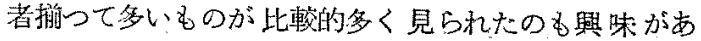
る. 透過性及び C. P. P. 因子炑就いては表 4 に一括す

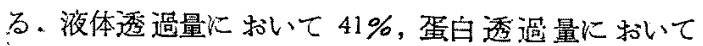
$13.1 \%$ の元進例数がある. 液体に比较すると蛋白は透過 乙難い事がかかる．C．P．P．因子量もや小增量してい 
表 4

\begin{tabular}{|c|c|c|c|c|c|c|c|c|c|c|c|c|c|}
\hline & \multicolumn{2}{|c|}{ 遮林速過量 } & \multicolumn{2}{|c|}{ 黑白透遇量 } & \multicolumn{9}{|c|}{ 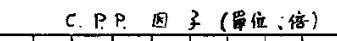 } \\
\hline & $\underset{4.90}{n}$ & $\begin{aligned} 5.00 \\
-8\end{aligned}$ & 439 & $\begin{array}{l}0.40 \\
4: 42 \\
0\end{array}$ & 陰 & 原 & 5 & 25 & 50 & 0 . & 2004 & & 600 \\
\hline \multirow{2}{*}{ 健庵古 } & $12+$ & 0 & 12 & 0 & $4_{\mathrm{er}}$ & 1 & 3 & 2 & $=$ & $=$ & 1 & 1 & \\
\hline & 100 & 0 & 100 & 0 & 34 & 8 & 25 & 17 & - & - & 8 & 8 & \\
\hline \multirow{2}{*}{$\begin{array}{l}\text { 鼻出血 } \\
\text { 患者 }\end{array}$} & 13. & 9 & 19 & 3 & 5 & 2 & 1 & 2 & $=$ & 3 & 3 & 4 & 2 \\
\hline & 59. & 41 & 86.9 & 13.1 & 23 & 9 & 4 & 9 & - & 14 & 14 & 18 & 9 \\
\hline
\end{tabular}

る淀例が多い事がわかる。

3）血液病患者に就いて

表 5 は學出血及び荬肉出血のために耳番科炕治療を传 頼されたすので, 白血病と紫斑病である。琹く入院加療 中のものである.

\section{表 5}

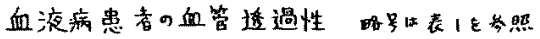

\begin{tabular}{|c|c|c|c|c|c|c|c|c|c|c|c|c|c|c|c|}
\hline 5 & \multirow{2}{*}{ 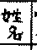 } & \multirow{2}{*}{$\begin{array}{l}42 \\
89 \\
\end{array}$} & \multirow{2}{*}{ 年 } & \multirow{2}{*}{ 病 } & \multirow{2}{*}{ 綮 } & \multirow{2}{*}{ 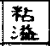 } & \multicolumn{3}{|c|}{ 值 } & \multicolumn{3}{|c|}{ 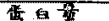 } & \multicolumn{2}{|c|}{ C.P.P. Ply } & \multirow{2}{*}{ 委 } \\
\hline 景 & & & & & & & $F=$ & t大t & 美 & F & +2 & 7 & 因子 & 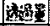 & \\
\hline 1 & Not. & 9. & 13 & 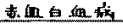 & 5 & $\begin{array}{ll}5 & 14\end{array}$ & 23.0 & 230 & +0 & 6.3 & G. 3 & 0,0 & $\ldots$ & 1,00 & $+\infty .00$ \\
\hline 2 & $s p$ & 9 & 13 & 白血瘁 & - & - & 420 & 420 & 0,0 & E. 7 & 8.5 & 0.2 & $25<$ & 1,00 & -0.02 \\
\hline 3 & s.s. & 5 & 57 & & 80 & $5 \quad 11$ & _- & - & - & & $=$ & $=$ & 25 & $=$ & - \\
\hline 4 & $G, n$ & 8 & 63 & & 40 & 66 & $=$ & $=$ & - & $m$ & - & - & $\cdots$ & $\ldots$ & - \\
\hline 5 & n. & 5 & 33 & & 䦄数 & $\begin{array}{ll}8 & 20 \\
\end{array}$ & - & - & $=$ & $=$ & - & $=$ & 67.5 & - & $=$ \\
\hline 6. & $\mathrm{KH}$ & 9 & 9 & $=$ & 器器 & 310 & 440 & 38.5 & 5 & 6.5 & B.3. & $\Delta, 2$ & 200 & & $+0,19$ \\
\hline$?$ & ru. & 9 & 9 & . & 45 & 518 & 305 & 295 & 10 & 6.5 & 6.3 & 0.2 & 25 & 3.28 & $+0, \cdots$ \\
\hline A & 5.4 & $\hat{6}$ & 8 & 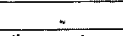 & .73 & 210 & 315 & $3 a 0$ & 1.5 & 6.7 & 66 & 0.1 & 200 & 4.76 & +0.25 \\
\hline 9 & $Y K$ & 온 & 10 & 篓然病 & 無犃 & 0 & 450 & 43.0 & 2.0 & 67 & 6.6 & a.1 & 5 & 444 & +024 \\
\hline (f) & ES & 5 & B & & 6 & $\begin{array}{ll}3 & 8 \\
\end{array}$ & 43.0 & 41.0 & 2.0 & 7.5 & 2.5 & e. & 5 & 465 & +0.34 \\
\hline 11 & rs & 8 & 6 & 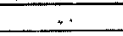 & 22 & 411 & - & $=$ & - & - & - & - & 5 & -1 & - \\
\hline 12 & H.H. & 5 & 23 & , & 急 & 68 & 28.5 & 283 & a.2 & 6.1 & 5.6 & 0.5 & $\ldots$ & 0.67 & -0.4 \\
\hline 13 & IE & \& & 14 & \pm & 7 & 22 & 242 & 220 & 2.2 & 5.6 & 5.3. & 0.3 & 100 & 8.33 & 0.23 \\
\hline & $S T$ & b) & 15 & . & 60 & $\begin{array}{ll}3 & 8 \\
\end{array}$ & 35.5 & 33.5 & 2.0 & 6.8 & 65 & 0.3 & $1 \rightarrow 1$ & 4.22 & +0.8 \\
\hline
\end{tabular}

その成續は皮膚溢血斑数は 13 例中 10 例が病的に多 く, 粘膘溢血斑数は13 例中 11 例が病的であり，共に全 身的な毛細血管抵抗性の弱化を物語る。乙机にる拘ら ず，毛細血管の透䎠性が病的に光進している症例は，液 体透遄性では症例 13 の1 例のみ，蛋白透過性では 皆無 である.毛細血管の抵抗性と透過性との根本的な相違を 觉せつけられる。併乙，蛋白透過炕いて負の符号を有 する者が少ないことを見逃してはならない。

C. P. P. 因子量绀表6で 200 㥉以上のむのが正常例

\section{表 6}

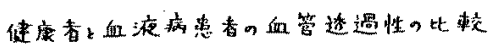

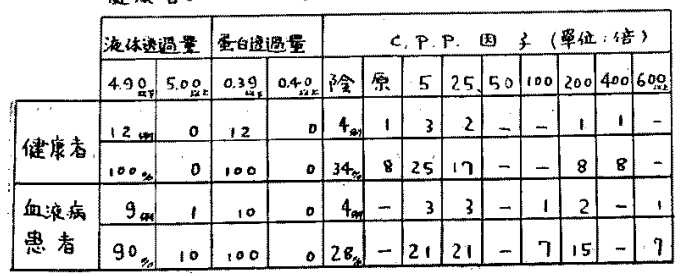

において16\%，血夜病患者比いて22\%である。異常 例がすべて白血病なので，白血病だけに対してる8 例中 3 例で $38 \%$ 弱であり，白血病の C. P. P. 因子は增量 しているとはい光ない。この表で目だつのは，毛細血管 の脆可夝を示病的に多、溢血斑数である。

4）アレルギー体覧者に就いて

表7はアレルギー性症状を過去又は現在に明白に有寸 る者の成緢である。发佮溢血斑は 14 例中 5 例の36\%弱，

\section{表 7}

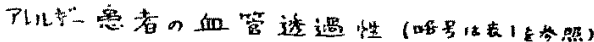

\begin{tabular}{|c|c|c|c|c|c|c|c|c|c|c|c|c|}
\hline & & & & & & ） 值 & & & G & & & \multirow{2}{*}{ 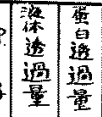 } \\
\hline & & & & 湴 & $\sqrt{ \pm}$. & 齐 & $\frac{y_{2}}{x_{2}}$ & 压 & 就 & 差 & 回了 & \\
\hline & 5 & & & ${ }^{2} 5$ & 38.2 & 364 & 1.8 & 6.4 & & 0.1 & & \\
\hline & & & & O & 34.0 & 325 & $|1.5|$ & 509 & 49 & 1.0 & $200 \mid$ & 4.41 \\
\hline & & & & & - & - & - & -1 & - & - & & - \\
\hline & & & & $0_{3}$ & 36.0 & 35.0 & 1.0 & 89 & 8.5 & 0.4 & 100 & \\
\hline & & & & ${ }_{13}$ & 303 & 228 & 75 & B.1 & & 2.2 & 62.52 & \\
\hline & & & & $6_{13}$ & 40 & 42.0 & 3.0 & 6.7 & 63 & 0.4 & 625 & \\
\hline & & & & ${ }^{\circ} 7$ & 9.5 & 35.0 & 4.5 & 24 & 70 & 04 & & \\
\hline & & & & & 460 & 450 & 0 & 7.0 & 67 & 0.3 & $\Leftrightarrow$, & \\
\hline & & & & ${ }^{\circ}$ & 46.0 & 42.0 & 40 & & 7.0 & 0.8 & 25 & \\
\hline & & & & {$\left[\begin{array}{l}0 \\
2\end{array}\right.$} & 34.0 & 30.5 & 35 & 6.7] & 6.3 & 0.4 & 51 & \\
\hline & & & & 0 & 328 & & 1.8 & 7.4 & 9.4 & 0.0 & $1,-1$ & 4.76 \\
\hline & & & & ${ }^{\circ} 3$ & 495 & & 9.5 & 6.0 & - & - & 400 & 1819 \\
\hline & & & & $1^{0}$ & 80 & & 0.5 & - & 66 & - & 400 & 1.25 \\
\hline & & & & & & 39.5 & & 6.8 & & 0.4 & $400]$ & \\
\hline & & & & & & & & & & & & \\
\hline
\end{tabular}

粘臊溢血斑は 14 例中 3 例の $21 \%$ 强が異常值走示し, 異 常值を有する的の>数がや>目につく．

所が，液体透過性の光進例は 舅出血患者の $41 \%$ を上 廻る50\%を示している. 更に，蛋白透濄性も鼻出血患 者の $13 \%$ もしいで $17 \%$ の例見られている。

表8觉ると，C. P. P. 因子量子 200 倍以上のもの がフレルギー患诸では $46 \%$ と全数の半ばに近い．

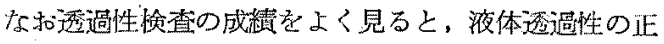
常例 7 例中 4 例末でが，限界值の 5 亿近い 4 以上の值を

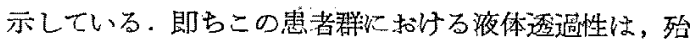
えど大部分が巽常值か，あるいは異常值に近、伯示し ている事は明確である. 㕛蛋白透遗性沉むいても，負号 を示すものが少く，一般に正常者に比较す机ばや小充進 している状熊と云える。 
注目すべきは，蛋白透過性の翼常を示す2例はいずれ

\section{表 8}

\begin{tabular}{|c|c|c|c|c|c|c|c|c|c|c|c|c|c|}
\hline & \multicolumn{2}{|c|}{ 挍体速䢔量 } & \multicolumn{2}{|c|}{ 蛋白透谓星 } & \multicolumn{9}{|c|}{ 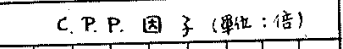 } \\
\hline & 4.90 & 5.00 & 0,39 & 0.40 & 㓌 & 原 & 5 & 25 & 50 & 100 & 200 & 400 & 600 \\
\hline \multirow{2}{*}{ 健唐者 } & 12 & 0 & 12 & 0 & 4 & $t$ & 3 & 2 & - & - & 1 & i & - \\
\hline & 100, & 0 & 100 & 0 & 34, & 8 & 25 & 17 & - & - & 8 & 8 & - \\
\hline \multirow{2}{*}{$\begin{array}{l}\text { P以甘゙- } \\
\text { 患香 }\end{array}$} & $7_{i n}$ & 7 & 10 & 2 & $3_{0}$ & - & 3 & 1 & - & 1 & 2 & 3 & 2 \\
\hline & 50 & 50 & 83 & 17 & 20, & - & 20 & 7 & - & 7 & 13 & 20 & 13 \\
\hline
\end{tabular}

も液体透逜性の異常を伴っている事で方る，又全体と して液体も蛩白も透過量は正常例よりも一般に元進して いる.併し表7で，個々の症例ではとの数值に平行関保 がない事も明白である。

次に極端に液体透過性の亢進していた10 以上の透過 量を有する4例就いててレルギー症状を検討してみ た.

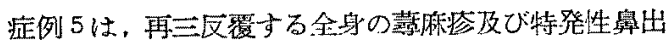

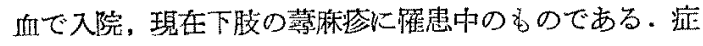
例 7 は時々食あたりをするという程度であるが，症例10 は顕著なアレルギー症状を有している。即る中華とばに よる全身套麻逡は必発で,こ〉 3 力月来魚類, 肉類に因

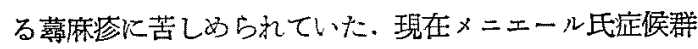
で入院中検查した例である，症例 12 は 23 才の青年で子

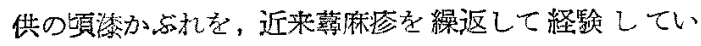
る,

要するに，液体透過性が強く立進している证例は，現 在アレルギー状態にあるか，あるいは民覆寸る顕著な了 レルギー症状を，破江極く最近に示したものに多い上ら である。但し，液体透過性光進の少ないものは、フレル ギー症状が明確でないとは云えない，たよ゙，艺の上うな 傾向が見られるというので，フレルギー症状が液体や蛋 白の透過量と平行して強くあるいは弱く現れるといらの ではない，即ら、フレルギー症状には血管透過性が大い に関係するが、これだけが全部ではないという事であ る.

5)（i）慢珄剧奥腔炎患者に就いて

表9は本院耳鼻科を訪水た外来及び入院の漫性副鼻腔

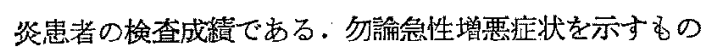
屯あるが，大部分は中鼾介，箒骨胞等の肥大や鼻茸等を 有士る著明な副鼻腔苝症状を持ち，急性增恶淀状を欠く むのである. 皮虏澄血斑数 20 個以上のものが 15 例中 5 例 $33 \%$ 强であり，粘膜溢血斑数の異常値を示すもの
表 9

慢性副量腔案恚者血管透過性

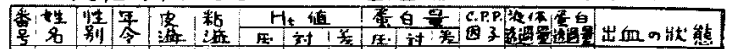

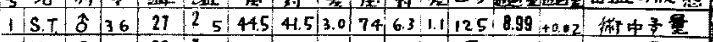

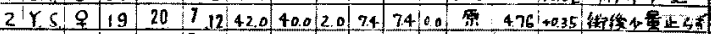

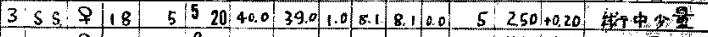

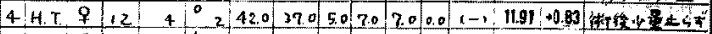

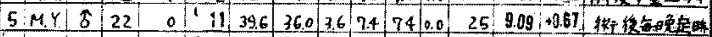

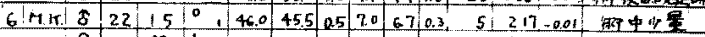

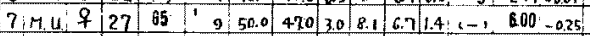

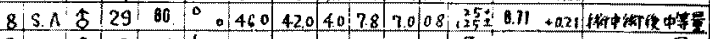

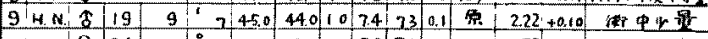

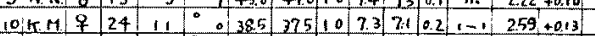

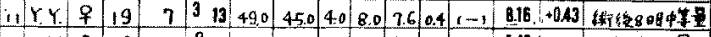

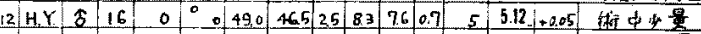

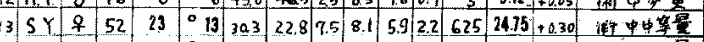

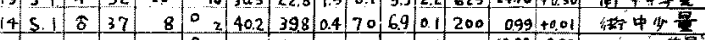

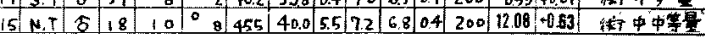

が 15 例中 6 例 40\%ある。

この溢血斑数を手術時の出血状態之比較すると，少数 例なので統計的に㕕ネする訳ではないがこっでる明白 なよらに，雨者間の関俰はかなり高度に一致する、澄血 班数と手術時の出血傾向に就いては, 前記の茾上の諭交 を参照されたい.

次以透過性学ると，液体では15例中9例(60\%) が，蛋白では15例中 4 例（27\%）が病的である。しか

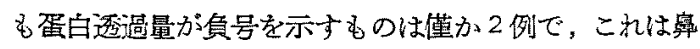
出血やアレルギー患者の場合に似ている：この関俰性 表10により明らかである。

表 10

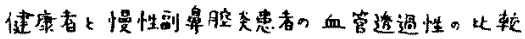

\begin{tabular}{|c|c|c|c|c|c|c|c|c|c|c|c|c|c|}
\hline & \multicolumn{2}{|c|}{ 淁体连洞星 } & \multicolumn{2}{|c|}{ 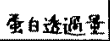 } & \multicolumn{9}{|c|}{ 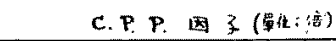 } \\
\hline & 4.90 & $5.0 \%$ & $0.39_{4}$ & 0.4 .0 & 阾 & 舟 & 5 & 25 & 50 & 100 & & & $6 \alpha$ \\
\hline \multirow[b]{2}{*}{ 健康者 } & 12 & 0 & 12 & 0 & 4 & 1 & 3 & 2 & & & 1 & & - \\
\hline & 100. & o & 100 & a & 34. & 8 & .25 & 17 & - & - & 8 & 8 & - \\
\hline \multirow{2}{*}{$\begin{array}{c}\text { 副䛲䏠 } \\
\text { 患 者 }\end{array}$} & 64 & 9 & 12 & 3 & $4_{n}$ & 2 & 3 & 1 & $=$ & 2 & 2 & - & \\
\hline & 40, & 60 & 80 & 20 & $27_{4}$ & 13 & 20 & 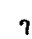 & - & 13 & 13 & & 9 \\
\hline
\end{tabular}

な挔表9で溢血斑数と透過性は必ずしも平行していな

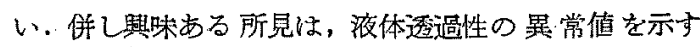
10 例中 8例までが，出血の異常を示す事である。即占， 溢血斑数之液体透過性と出血状態は，全例が必ずし平 行子一致的しないが, 相当数までは共通に病的である症 状がある事がわが。

次に C. P. P. 因子であるが，表10のよらに徤康者 と比較しても殆んど差が認められないといら特異の所見 である。

次に表11を見ると。 
表 11

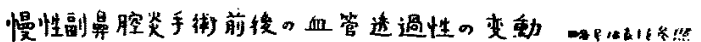

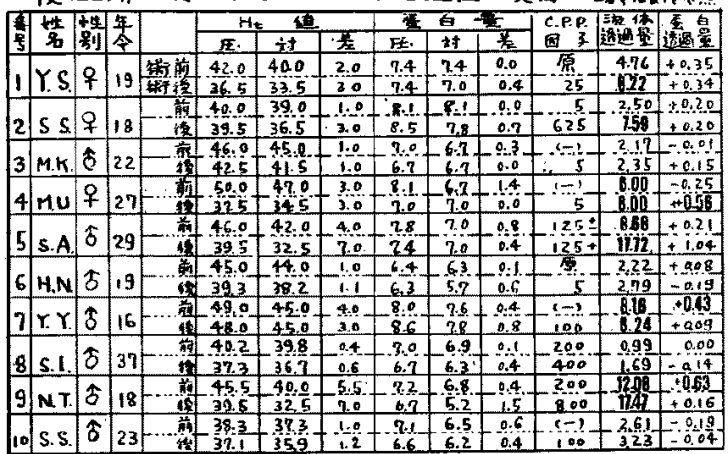

(ii) 副鼻胵手術の影響

前項に述べた副楀腔炎患者中，任唱に抽出した10 例

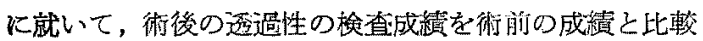
してみた，検查成續はすべて術後 2 日以内のものであ る，術後の液体透嵒性の充進例は 10 例中 9 例の 90\%で ある．反之，蛋白透䢔性は光進が 4 例，低下が 5 例，不 变が 1 例となり，液体透過性に平行しない，液体透過性

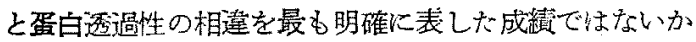
と思う。

C. P. P. 因子法術後沁必ず增加すると云光る程全例が 変化して，殆んぞ例外もない，しかも症例 7 を唯一の例 外として大体 C.P.P. 因子の增加之伴って, 液体透遇量 が增加している，併し一方出血の影䇾を教党ると，検查 成樍が-すべて術後 2 日以内のものであるから，失血量が かなり判然と Hematocrit 值涀れていると孝える. 即 ち、術前・術䀠の Hematocrit 值の差から出血量が推察 できると考える、計算されたこの差は，C．P．P. 因子 量の消長の程度と必ずしも平行していない，これ等の関 俰流いては，後で考按する事にする。

6）失血子 C. P. P. 因子との関係

表 12 は，本院血液銀行を訪れた職業的供血者のC. P. P. 因子量である：C. P. P. 因子量以外の成續はす へて血液銀行に和ける測定資料に基つくくのである。採

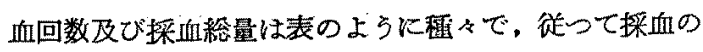
C. P. P. 因子量に対する影㮩が，色ヶの場合に観察でき る.

C.P.P. 因子と血夜型との関運を見ると，特別の相互 関係は無さとうである. 血王に就いても同様に C.P.P. 因子汇影響を及ぼすよな関係は認められない。

体重江供血者は皆同程度であり，C.P.P. 因子との関

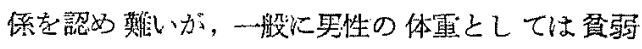
で，供血者の境遇を反映しているようである，次に 拆血量と C. P. P. 因子の関俰であるが，採血回数 が调去了回で600cc のものを見ると，陰性から800 倍泻り，採血量 $1000 \mathrm{cc}$ 以上 $5600 \mathrm{cc}$ までのbの るやはり陌性から 800 倍迄で，剛者間に差はない。

血清蛋白量と C. P. P. 因子との関係も，蛋白量 6.7 以下の 4 例子, 关の他の 6.7 以上の例も共に陰性

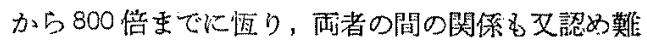
W.

\section{B 動物笑験成績}

1）娐過と溢血の場に関する観察

実験方法の項で述べた方法により，循環系に注入

表 12

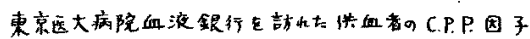

\begin{tabular}{|c|c|c|c|c|c|c|c|c|c|c|}
\hline & 性名 & tax & 年令 & 索 & fm. $x$. & 体重 & 䨞白里 & 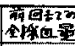 & 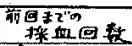 & $\begin{array}{l}c, p, p \\
\text { a, }\end{array}$ \\
\hline 1 & E.T & $\hat{\delta}$ & 42 & A & $130-70$ & 50 & 74 & $2800^{\circ \mathrm{c}}$ & $5.31+2.25, \rightarrow$ & 5 \\
\hline 2 & Y. J & $\delta$ & 30 & A & $120-70$ & 59 & 76 & 600 & $\begin{array}{r}5.3 .17 \\
30\end{array}$ & 0 \\
\hline 3 & ZF & 5 & 38 & 0 & $130 \sim 70$ & 49 & 70 & 5600 & 5.30.9.15 $\overrightarrow{0}$ & 5 \\
\hline 4 & I. H & $\delta$ & 40 & $A$ & $100 \sim 70$ & 54 & 1.0 & 400 & $\overrightarrow{2} \cdot \vec{\theta}$ & - \\
\hline 5 & k. $r$ & t & 36 & 0 & $110 \sim 70$ & 55 & 7.6 & 600 & $\begin{array}{l}245 \\
30\end{array}$ & 260 \\
\hline 6 & A.M & ह & 25 & 0 & $120-70$ & 50 & 7.0 & 200 & 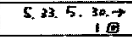 & 25 \\
\hline 7 & k. $s$ & 8 & 51 & $o$ & $160 \sim 100$ & 55 & 7.2 & 5000 & $\frac{c 2}{250}$ & 0 \\
\hline 8 & $T M$ & $\delta$ & 31 & B & $140 \sim 70$ & $4 n$ & 6.7 & - & i力 & 营 \\
\hline 9 & k. T. & $\hat{s}$ & 39 & 0 & $140 \sim 90$ & 51 & 7.1 & 1000 & $\overrightarrow{i \vec{a}}$ & BDo \\
\hline 10 & E.L & $\tilde{\varepsilon}$ & 50 & 0 & $140 \sim 70$ & 53 & 6.4 & 3600 & 5. $1149 \overrightarrow{9}$ & 5 \\
\hline 16 & T.Y & 8 & 68 & A & $150-85$ & 50 & 7.3 & 4200 & E. 30. 11.247 & 䆑 \\
\hline 12 & $1 Y$ & 2 & 27 & A & $130 \sim 80$ & 50 & 6.3 & 200 & 5. 33.5. $: \overrightarrow{0 a}$ & 800 \\
\hline 13 & $K G$ & 9 & 38 & A & $110-70$ & 45 & 6.0 & 600 & 33. 1.150 & $a$ \\
\hline
\end{tabular}

された微粒子の色萃 Trypanblau は，その儘血管系を 循環していて，皮有にはなかなか現れない，粘脱では先 らでないが，これに関して性次項で述べる. 所が人の場

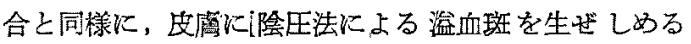
之，血管内の色素子外へ透過してくる，透過野は使用し

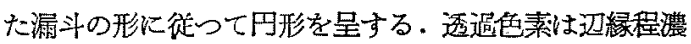
く，中心程薄くなる．この透過野の内に溢血斑も生ずる 訳であるが，泟血斑はその数も密度も，透强の程度を示 与青さの濃淡とは全く無関保に散在している。文辺縁に 近く所謂迅縁溢血斑 (Randpetechien) る存在している が，その密度の大きな所化ずしも色菜が多く颓過して いる事るない。

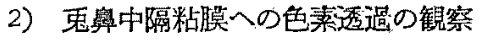

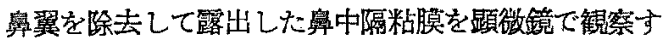
ると，視野に毛細管やこれより太い細動・静脈と思われ る血管内を血球が流れている状態がよく見方る，この場 合毛細管と稩動・静脈の血流の方向は必ずしも一定では 
ない、丁度闭者か逆の方向に流机ている所を㩆微鏡下に 見ていると、耳から入れられた Trypanblau は必ず細

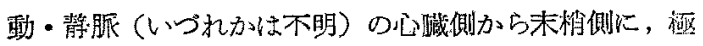
めて速やかに洪水が汇監するように出現する。沃して毛 細管の流れと一致しない，要約すると次の上らでする。

a) Trypanblau は決して毛細管の血流に沿つて透嵒

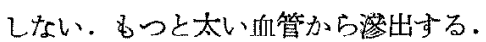

b）必ず血流の心臓側加ら末梢側へ出る。即ち細動・

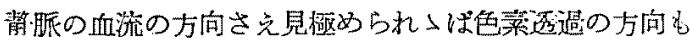
判然とする.重要な事は，毛細管は血球の流れが判然と 見られるが，細動・静脈では血流が速くて方向が判然と しないこの時，内・外いつれかの頸動脈を王迫する と、いずれの場合もとの局所の血流は緩徐となつて方 がわかる。

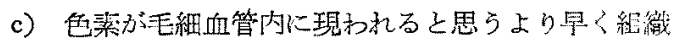
間陸に出現する。

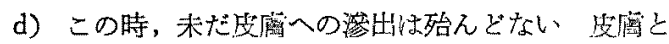
粈膜の透通性の相違であらう。

〔势】上述の細動・静脈とは, 50 ミクロン以上の直 堡を有する血管である。

\section{VI 考按}

1) Eppinger の式厄裁いての批判

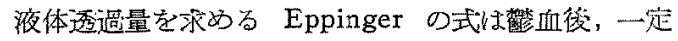
量の血液から液体成分が涔出した时の数学的な差引を, Hematocrit 值の差に求めたるので方る。例之ば，水之 耖の入つたバケッから水だけを没及出すと，砂の全体以 対する容蕒比が大になるといつた理屈である、従って血 纴とか，血管壁の膨脹とか，30 分間の压迫に因る呩維部 と艺の他の部との液㑣成分老均等化するために起る交洗 などは当然開題となるが，これ等化詨する考慮は含まれ ていないこの事は，蛋白透過量を求める式でる考光ら れる事である。

即ら，一定量の血液から液体成分のみが透過した場 合，消失した液体の量は上述の原理に基すいて Hema. tocrit 値から求められる. 当然血清胥白心涨紽されて, 蛋白量の比は上等する、乙かもこの時の蛋当聂は液体透 偲量から計算できる。この数值と夷際の湘定值との差 が，蛋白透通量である。

又, $40 \mathrm{~mm} \mathrm{Hg}$ Q仕迫に打古克つて流出与る近流も市 る訳で，殊に䢐圧の高い人ほどその傾向は大きい、従つ て圧迫に因る影譩は少なくなる。この血圧による調整 は，实験例の夹々の一例づつに行なわなげればなるまい が、そうなると各症例の血管壁の弾力性とか，自律神経

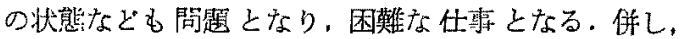
Landis の测定法はこれ等の因子が総合された結果の測 定であり，各应例の圧迫といら外力に対する反広の相違 が出るのであるから，奏際には充分参考となる成績であ љ.

又, 血液の粘稠度は血潜蛋白量比由笑するので, 血管

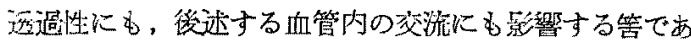
る、即ち，粘稠度の大である程交流す通過むし難いであ らら.

その他，文献的考察の項で述べた諸因子（西丸）も多 少は関与寸るであろうが，奏際の血管透過性の測定に大

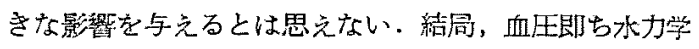
的壬美之, 血清蛋白量即ら液体成分の粘椅度の 2 つが，

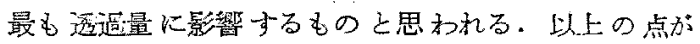
Eppinger の式の弱点と見做せると思う。

それでは，実際上血圧や血清蛋白量が血管透蛊性に対

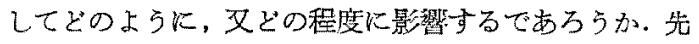
ず血圧は著者の症例では問題にならない、なぜなら著者

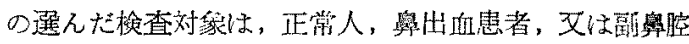
の手術をした㭧者などで，伹圧は正常か窑ら低い者のみ

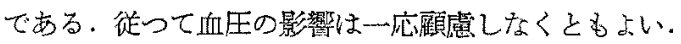

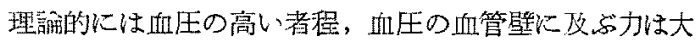

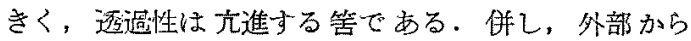
$40 \mathrm{~mm} \mathrm{Hg}$ の圧力が加和水ぱ，血管外加占内部几及ら 力も大きい。この2

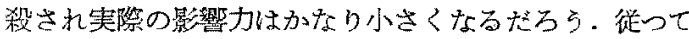

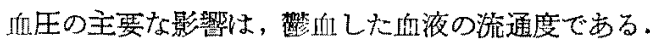

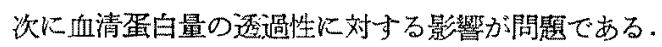
先づ Manchette による比較的大きな王迫を上腕に加壳

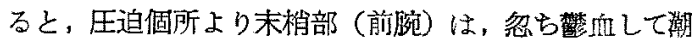
紅する.併し, Landis 法による弱い王迫では，これに

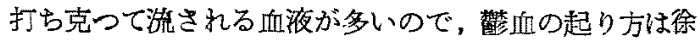

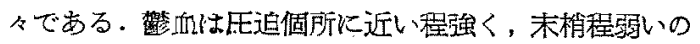

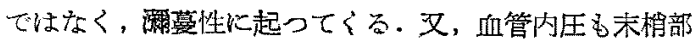

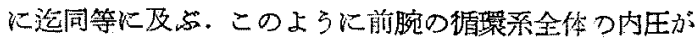

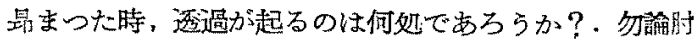
静脈の上らな壁の厚い血管ではない，普通とれはま細管 でもない事は，前述の動物奏駼でも推察できる，結局天 野のいら細静脈あたりで透過方起るのであるら。たよ゙透

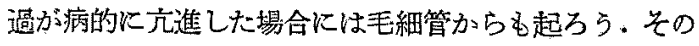
結果血液成分比の変化，即ら液体あるいは蛋白あるいは 可者の濃縮が起る、盰静脈にもこのよらにして、濃縮さ れた血夜が流れるようになる。この变動は比較的短時間 


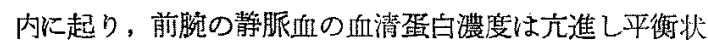

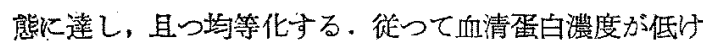

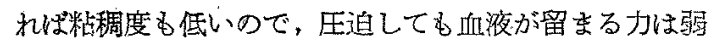
く，そのま上流れ去る可能性が大さい，実際にとの湘定 値はや>低目の值が出るであらら。

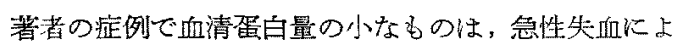
るものと考えられる、慢性失血の場合，堂外な程血清琶 白量方減少しない事は，表12の職策的供扔者の例を見 ればわかる．血清蛋白量が減少する他の場合として，策

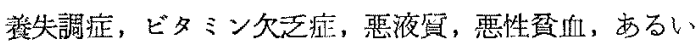

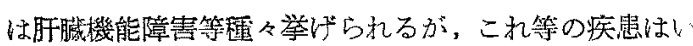

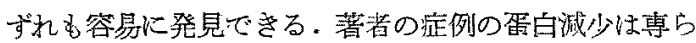
失血によるもので，徒つて多くの例で同時に血圧の低下 を認めている。

血压の高い場合む，低い䭪会も，面液は压迫個所を通 過してしまら可能性があり，伹清蛋白量の测定值はいず

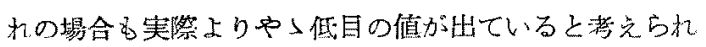

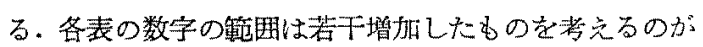
罗当であらう、いずれに世よ各表の成斜はこれ等の事情 を一応念頭に置いて考察才べきである。

このよらに Eppinger の式には種々の久点歹あるが，

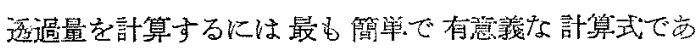
り，液体及び蛋白透過量の軕方に応用して差交光ないと

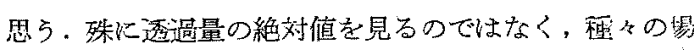

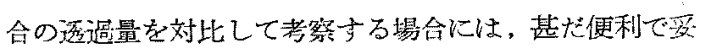
当でるあると考当る。箸者が敢てこの計算式を採用した 所以でるる。

2) 煡庵者心僦いて

特に目だっのは C. P. P. 西子を予想以上に䈍々有子 る者がい事である。しかる C.P.P.因于量と Landis

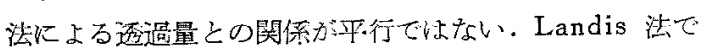

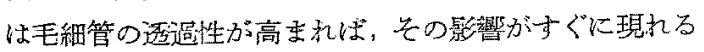

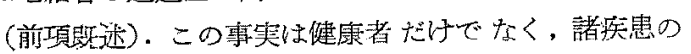

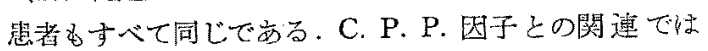

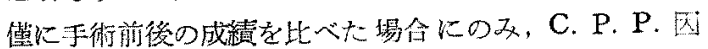
子量之透過量とが平行子る位である.C.P. P. 因子炕

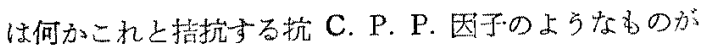

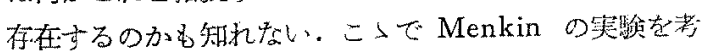
案してみると，彼の方洗による家鬼の腹壁での突踰で，

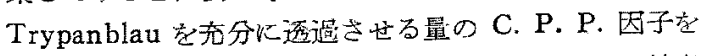

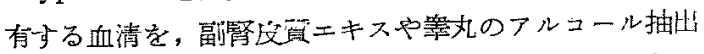
液等と共に便用すると，色瑟の透橾を完全に折制できた という.この場合の抗 C. P. P. 因子ょ5の作用は，
Hormone 预統のむの上も考えられる. Cortisone が病

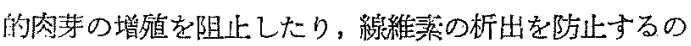

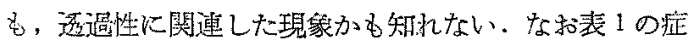
例9のように，粘莫澐血斑数からは血管の脆弱が考えら

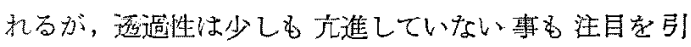

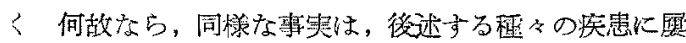
々H現するからである。

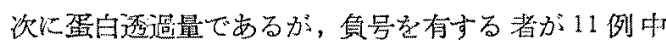
7 例它る。前述の上うた Eppinger の式は梗めて微

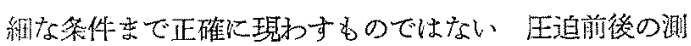
定值の比較加推䇥した純計数的なもので，坐体内の変

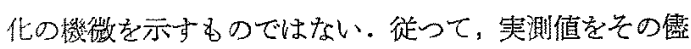

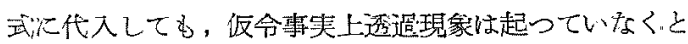

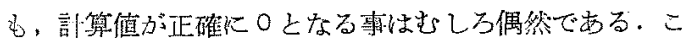

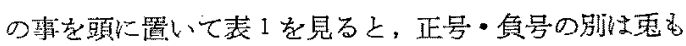

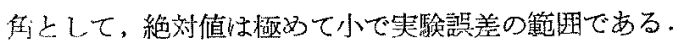
この○に近い值で蛋白透䢔の有無穵云々する事は無理で ある。

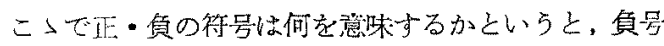

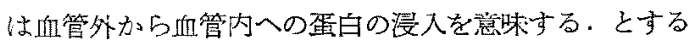
と，正負の差は絶対值が小だからと云つて一顧の洒值も ないるのとは思えない，一方の液体逐遣性でも，絶対值

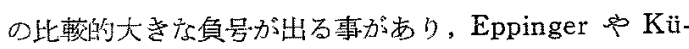

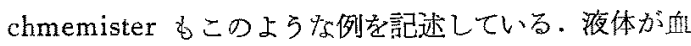
管内へ逆に浸入する場合，この液体内の蛋白加，たと充

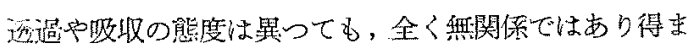

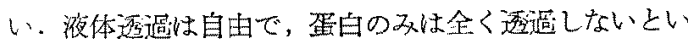

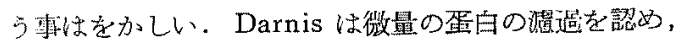

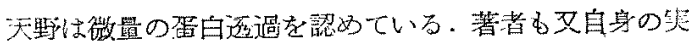

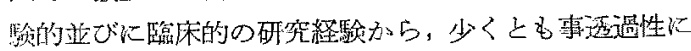

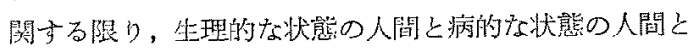
の区列が，非常に判然としたものとは考克鹳い殊に病 的扰態の場合には，蛋白の血管内人の再吸收があるに㮰

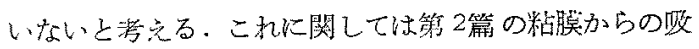
收の所で述べる。

表2には C. P.P. 因子の量とい5ものが同一人でる

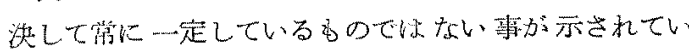

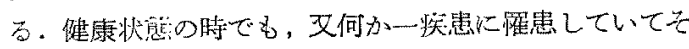
の経逼中でも，又の時々の身体の状態いか九で，C.P.P 因子量が常以陲子る事を示している。

C. P. P. 因子以就いては，Menkin はそれが組織細

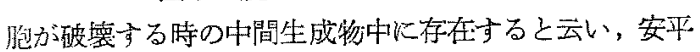
はこれを炎症举におげる組織蛋白の，異常中間代謝産行 


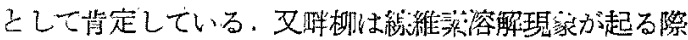
R，C. P. P. 因子が登生する事以注目乙，こ机は艘 蛋白の分解倸よつて生ずるるのと推察している，著者は 後述するように，アレルギー患者の C. P. P. 因子が， 健康者上りも著明に增量しているのを発見した。こ机は 抗原抗体反応に際して産生されるのではなからうか子想

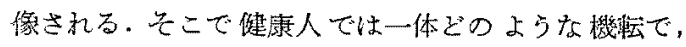
C. P. P. 因子が座出されるのか，Menkin の告見を聞 きたい点であり，甚た與味深い所である。

3）奥出血及び咽頭出血患者に就いて

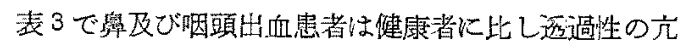

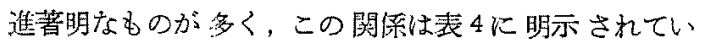
る. C. P. P. 因子む增加しているるのが目立つ. 即ち， 200 倍以上の C. P. P. 因于量专有する9例の中 5 例士 5.0 以上の液体透過量を有している。居之，C. P. P. 因 子量が 125管以下の 10 例中, 疗例 10 の1 例以外液体 还過量はすべて生理的動摇籍囲内である.しかもC.P.P. 因子 400 倍以上の症例は, 数值的炕は必ずし。液体透過 性之平行しないが，殆んど皆液休透遇量が多い，同樣の

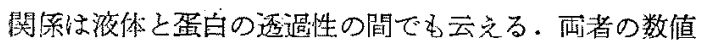
こ艺平行しないが，掻白避遗量の多い症例 10，11 及び

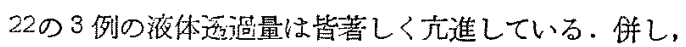
C. P. P. 因子量と蛋白透邀量は全く筫関係のようであ

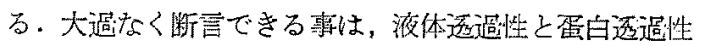
は完全に聶行するものではないが，閏者間には相当の関 連が㘯るといら东である。

又，C. P. P. 因子量自体は直授鼠出近の発現火は影 留していない液体逜遇性の九淮を起している全身状態の

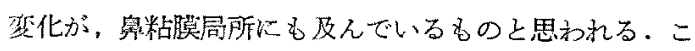

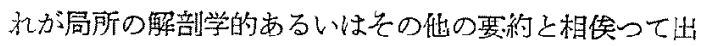
血の発現を助長するものであるら。

一方粘臊溘血斑数から血管の脆弱性を推察できる 10 例の中の6 例は透過性の㠵進学伴っている. 殊に淀例 8 などは，液体透過性，血管の脆弱性及び C. P. P. 因子 量なぞ皆病的である。この例㦋明なつレルギー体面者

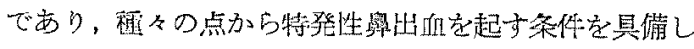
ている、特発性率出血患者老検討して及ると，その特翼 性はこれ等三画の病的条作を亲麻している事が多い。こ 机怡踺康者邑血液病患者汇は見られない事で，後述のア レルギー体筫者の場合にや〉似ている，更に透過性のみ ならず吸收性に就いてもフレルギー的な状態之一圈類似 してくるが、これに就いては第 2 篇に棭る。

特登性奐出血の発現儿は，局所的な形態的特異性に，
局所の血管の腈弱化（北上）乃至これを落起する病的要 䄪，更には上記の全身的な病的要因なぞが累加している 琭は確かである. 従つて局所と全身の両方の検穼が必要 である。

4) 近液病患者飞就いて

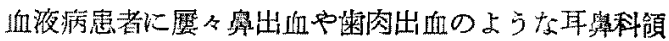
域の出血学起し，殊病氛の末期になると多いるのであ る。特に白血病之若年者の血小板減少性紫斑病は，耳舆 科医が接与る機会が比較的多い，著者はこの二突患に就 いて莩㨽性を調べてみた。

血液病は一般に出血時間の延長, 血小枢数の減小等, 出血因子が多いといら蒜告は既にある.著者の研究で は，表5に示したように，皮虞及び粘朕湓血斑数の著明 な增加により，全身的な毛細血管の脆弱性と，耳鼻科領 域の粘朕血管の脱弱性を知る事ができる。併し.C. P.P. 因子は健康者と比較して多くなく，又液体透過性も不思 議な程元進していない，この事寒は血管の透過性という ものが，多くの出血因子から独立していて，出血自体化

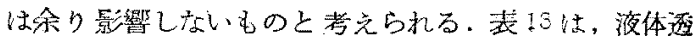

\section{表 13}

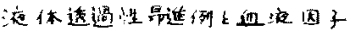

\begin{tabular}{|c|c|c|c|c|}
\hline & 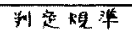 & 症例数 & 黑票湖数 & $\%$ \\
\hline C.P.P @3 & 125 湆 $3 \mathrm{~K}_{1}$ & 16 & 8 & 50.0 \\
\hline 赤血球数 & $48 \times 10^{4} \quad$ 12 & 15 & 3 & 20.0 \\
\hline 白但水敌 & 5000 & 14 & 4 & 28.6 \\
\hline & 9000 & 14 & 2 & 14.3 \\
\hline 血 & $.10 \times 10^{5}$ & 14 & $c$ & 0.0 \\
\hline 出组时细 & 5승 & 15 & 1 & 6.7 \\
\hline 续固时间 & $1+\hat{\theta}$ & 15 & 2 & 13.3 \\
\hline 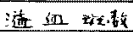 & 26 & 15 & 7 & 46.7 \\
\hline 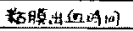 & $3^{3}$ & 10 & 2 & 20.0 \\
\hline 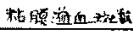 & $\pi 2$ & 14 & 7 & 50.0 \\
\hline 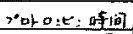 & $89 \%$ & 6 & 3 & 50.0 \\
\hline 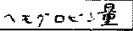 & $+e^{\xi / \alpha}$ & 6 & $\circ$ & 0.0 \\
\hline
\end{tabular}

䧟性の亢進している症例を疾患のいかんを間方ず集計し たものである．最高值は50\%で，C. P. P. 因子と粘膜 溢血斑数々 Prothrombin 時間である. 皮虔浚血斑数 はこれに次ぎ，以下諸因子社ずつと低率である。液体透 强性と平行して消長する因子小ない．C. P. P. 因子で すら，低体还過性光進例の50\%に異常であるに過ぎな い. 即ち既述の細動・静脈加らの透過と，毛細管透過之 が必す゚しも一致して旮進するものではない事を乘知すべ きである. 粘朕溢血斑数や Prothrombin 時间に就いて

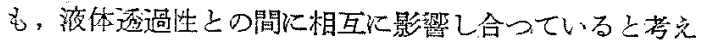
る上り，同時江共存した率が50\%と考光るべきである。 結局，液体透週性といら現象は独汇した特性であるとい 
う事が率える。

著者の検查では血液病患者には蛋白透過性の六進もな い.たさ稘号を示す例が全般的に少ない. Darnis のい 万蛋白透過性は，血管壁の性状の変化を条件とする，之 いうが少なくとす血管壁の脆弱性乃至は抵抗性の減弱を いらのではないらしい，事奉血液疬患者の出血傾向は，

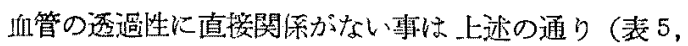
表 13)である. 即ち著者の検查成樍は一般常識の予期

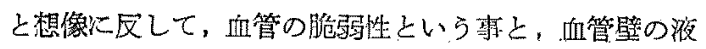
体及び蛋白の避過性というものとが明らが別個の独立 した血管の特貿である事を示したものである。

血液病末期の患者に時と乙て顔面や四肢の浮腫を認邓 る事がある。このよう忠者では，光の時の透過性や吸 收性を調べると，何か異常を認めるか子知れない，上も あれ，血液病で，C. P. P. 因子の增量をきたすような 組樴蛋白の分解が，大多数の祉例に起つていないような 結果が出た事は興味ある事である。

5）アレルギー体貝者に就いて

特発性鼻出血患者の中には，何かアレルギ一性背景が 西る者が多い事は既に述べた。いう造屯なくアレルギ 一現象は全第汇対する局所の関保が明確で，動物ならこ れを選び感作して、アレルギー状態をつくる承る可能で ある。併し，人間では，この者はアレルギー体貿である 之断定する事往々にして困難を感ずる。先づ抗原が不 明であつたり，過去の症状は患者の供述に頼らなくては ならなかいたり，文所謂アレルギー性疾患とされている ものが，梁して明確な根挑を有するか否かる不安であ

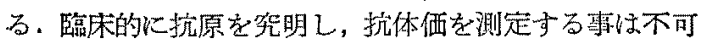
能な事が多い。

著者は問答と現应状とに上り、フレルギー性疾患とし

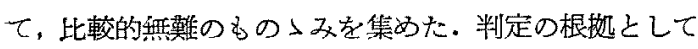

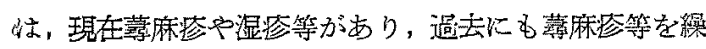
り返したとか，特定の食慨に常に胃腸症状を呈すると か，上気道の炎症特にアレルギー性與炎が著明だとか，

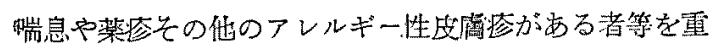
視した。

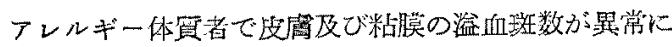

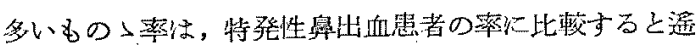
が少ない：これは舆出血患者がフレルギーた゚けを背景 としているのではなく，血管壁の脆弱化に関して他の要 因が加かつてい亨を示唆している。

表8で，液休透過性が充倠している者が半数あるが， これる罳出血患者に比較するとや小高晾である，加之，
蛋白透過性の元進例も方る，既述の各疾患でも，蛋白が いか煍過し難いかは明示されている。

又, C. P. P. 因子量む 200 倍以上の例が $46 \%$ (鼻出 血では 41\%) むある. 即ち, 透過性も九進し, C. P.P. 因子量も増量している非はアレルギーの特異性の一つ之 見做好る．と云うのは其際に過去にアレルギー症状が明 確にあり，現在もフレルギー症状が著名にある症例の方 が，透過性九進も C. P. P. 因子の增量も高度である。 逆にアレルギー症状の強い例は液体透過量の多、例中に 存在する事も既に実跲成續の項で述べた。

同様な関倸が C. P. P. 因子では更に明確である。

C. P. P. 因子睤の多い例は殆九ど現在了レルギ一症状

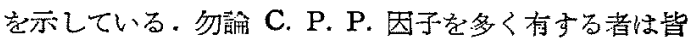
アレルギー体質者である，とは断定できないこれ惊健 康者の C. P. P. 因子量測定でる明らかである.たざ現 在著明なフレルギー症状があるものは，液体透遗性が元

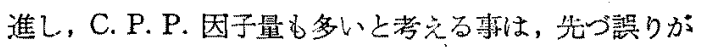
ないと断言できる。

著者が特発性幾出血とアレルギー体質との成績を特に 対比して見たのは，耐者の透嗃性やC. P.P. 因子量の 变動がや」平行的であるように感じたからである。恐ら く再者のこの現象は無関係なるのではするむい。

以上を総合すると、フレルギーに浮腫が伴つたり，発 疹が起つたりする事が多いのは当然で，又时に特発性に 又は他の動機から，出血し易い事などる理解できる。

5）副鼻腔炎蜆者に就いて

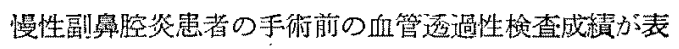

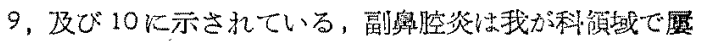

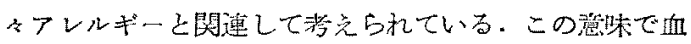
管透過性を追究し，关の方面から改好て副鼻㓐焱にいう ものを見るのも興味潹い。

表10でわかるように，本㗨舁患者には洨体逜過性の 充進しているものが過半数を占めている. 即ら，副鼻腔 资と全身透遗性が闑連している事を示与むのである。局 所病变と全身状態の相関関俰が推察できるが，この場合 同者を媒介するものは C. P. P. 因子ではないらいい。 C. P. P. 因子老 200 倍以上有方症例小，全体の $20 \%$

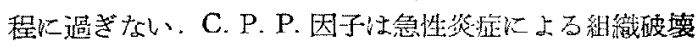
等化伴う蛋白分解から生ずる倳は，既迈の上らに各方面 で承認されている.慢性炎症では C. P. P. 因子量から 考充て炎症局所の病的活動は不活発である。結局，液 体透過過性克進物質は，アレルギーの項で述べた未だ本 態のはつきりしないるの、これを著者は抗原挖体反応の 
際の生成物と考えたい，作しアレルギーでは C. P. P. 因了量憎加しているが，慢性副鼻腔笑では比較的增加 している者が少ない。こっで著者は次ぎのような推理を した・慢性副學腔炎になる迄の再三の念性炎症の発現に は、フレルギー現象が雷要な役制を演じているのではな

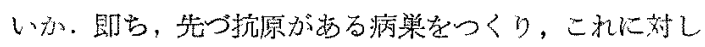
て抗作が座生される。この時期には C. P. P. 因子性增 量し，透邀性法九進寸る，今，抗原（多くは細菌性）が

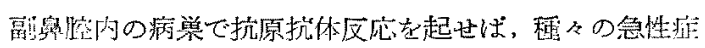
状方現れると其に透道性も C. P. P. 因子量も增加す る。仵し，この急性炎症が慢性化すると，組職蛋白の分 解は静止するから，C. P. P. 因子量性減少する。所が遼

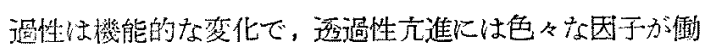

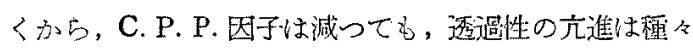
の要的によつて存綕したり，再現したりするのではなか

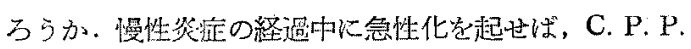
因子量の消長が起る。反之，逐语性は炎症の急性化以外 の多くの要的でも克進する.かくして, 表10の上万な 成績が出ると考皇る事もできる。

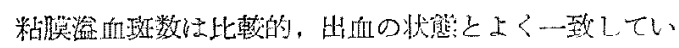
万。

慢性副翼拄炎が感冒などで，急性增恶を起すのは，上

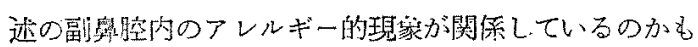

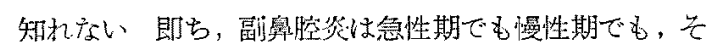

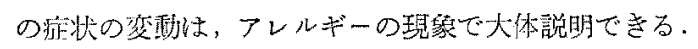

副舆腔手術行うと C. P. P. 因于が者しく增量し，

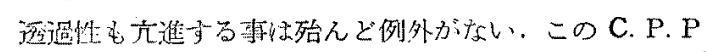
西子の增量には，三つの原因が考えられる。一つは手術 に上る神経的な影響であり，一つは手術時の外甥性失血

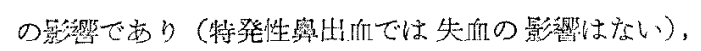
更に一つは組織の手術的浸學の結乐である.

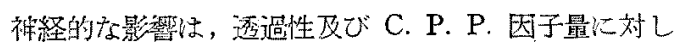

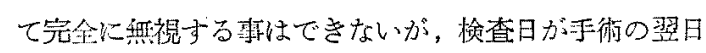
又翌々日なので，余り大きくはない．C.P.P.因子が

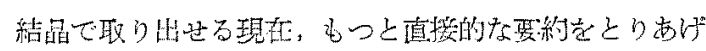
たい。

著者は手術的浸繁が，最も军要な関係を持つと考况

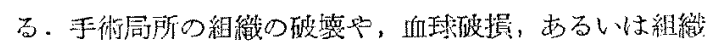
液の分解等に上って所謂 Menkin の諸因子が産生され

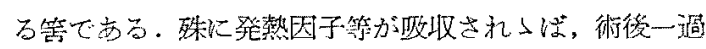
性の発熱即ち吸收熱を出すのは当然である。

失血そのものは蛋白分解を起さないので，C. P. P.

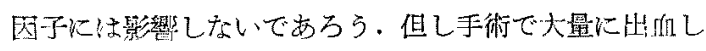

た場合は，蛋白量の急激な但下が直接透過性の九推をき たすだろう。

蛋白の透遇量飞関しては，術後增加の 4 例, 減少が 5 例，不変が I 例で，C. P. P. 因子の堦量とは殆えど無

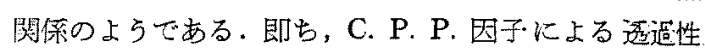
の目進とは蛋白に就ての弯ではなく，液体に就いての事 である。

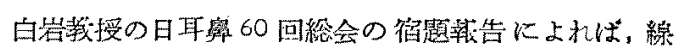

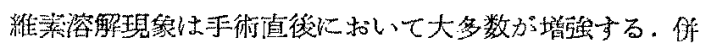
し，この事と出血とには明らかな関倸は認められないと

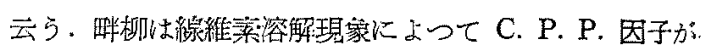
出現するだろうという。併し，C．P．P. 因子の增量と 出近とは直接の関係はない。

B. 動物実験に就いて

従来正常状態での栄荃交换は，毛細侣管部から行われ るとされていた，Krough や西丸は，泟楱類でTrypanblau の透過個所を追水して，これを絧状毛細管と集合 毛細管に認めて報告してい、。天野はマウスでの観察 で, 哺乳煩では Trypanblau の透遗は細静脈から行か れると報告した，併し Patentblau に対しては，細㲜 脈，毛細管の各部及び細静脈の全域からの娐遗を認めて いる・顕微鏡で細動脈か、紐静脈かを判定するのは困難で あり，彼は他の笑験の資料と合せて推誦しているのであ る.Patentblau は全域から透遇可るが，この色紊のみ

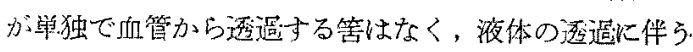
事恃当然である。即か，液体远避は毛細管及び細動・静 脈の全域から行われる訳である。併し Patentblau より 柽子の大きい, Trypanblau 加，生理的に細静脈から透 過し，毛細管方らは透遥しないといらのか゚事䒠なら，粒 子の大きい物質は法細血管上り細静脈の方が透過し易い 性質を有寸る事になる，更に大きい粒子の蛋白中墨汁 が，細静脈からのみ透過するといら事実(これ組織学

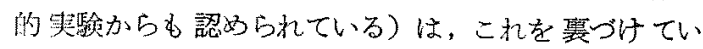

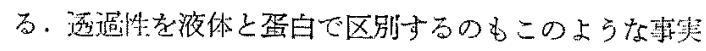
に因るもの上考完られる。

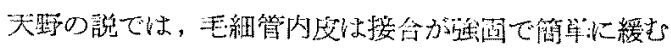
束はないから，赫血樂のような大きな粒于は管壁の不叮 逆的な破壊がなけ机ば，管壁を通遇し得ない，従つて。 汪細血管からは滤出性出血はあり得ないていう。この場

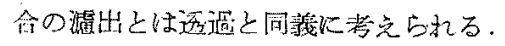

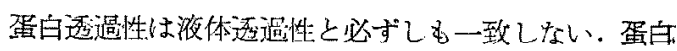
透過方容易に行和机い事は各筷患において述べた通り

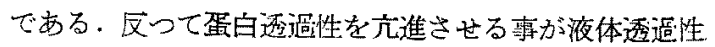




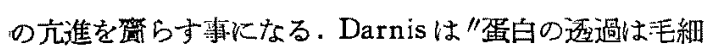
管壁の性質の变化を条件とする゙と云つたが，細静脈の 少しの変化は簡単以蛋白の透過部すらしい。この埸合 毛細血管の性状る二次的炕变化が伴らか子知れない。

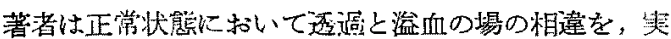
際に観察した（実験 $\mathrm{i}$ )

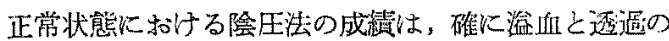
場の一致を示さない，湓䢐斑が毛細管の变化である事は わからているので, Trypanblau は毦細管から透過した のではない事がかかる。恐らく細静脈から透過したもの 之想像できる，細動脈は壁が三篔となり透過はむしろ因 難と思われる，更に太い血管では一譄困難である，渻者 の実験では湓血と透過の場に色紊の濃度差が起つた。艺 の理由は下記の通りである。澄血斑が発生する迄には。 相当強い陰圧と時間要する。この強い陰圧を一定時間 加えている中に，その影響が組織内に埋没している毛細 管上り大きく太表在性細静脈壁炕，上り容易に，上り 早く及心筈である. 従つて細静脈からの Trypanblau

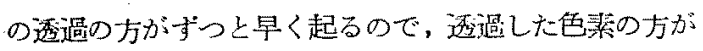
毛細血管の破糘個所から逸出する色菜上り，遥か炕多量 である、事突、溢血斑は生じない程度の弱い陰圧を加觉 ても，色菜の透過はその場所に起ってくる、両者の反応 の場の相違が判然と見別けられたのである。

(実駼 ii) 顕微鏡下に Trypanblau の透過の状態を, 外力（除圧など）を朋光ないで象の奥中隔粘腊で観察し た.こ〉でも，色素の透過場所が毛細血管でなく，細栜 脈か細静脈のいずれかである事が観察できた。從って既 述之同様の理由から, 細静脈からの透過の可能性が滍い と思われる。色素は粘䐺には瞬時の中に出現して透遇与 るが，この時期では未だ皮虏えの透過行行なわれていな い. 皮虞と粘朕に色素の出現する時間的の差から，両渚

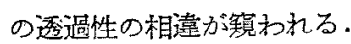

\section{VII 総括及び結論}

以上，著者は血管の透過性を践康者及び耳鼻科领域の 各矣患に就いて測定し，併せて透過性を艺進する因子の 一つである Menkin の毛細管透過性光進因子量をむ澌 定して，同者を対比検㨽した。

透過性は液体，蛋白及び血球透週性に大別できる，血 球の透過は細静脈で行なわれると推論できるが，これは 耳鼻科項域では日常比較的稀である。液体と蛋白の唀週 性に就いて得られた知見は，大要次ぎのようなものであ る.

1）液体透過性は蛋白透過性と必ざしも平行しない

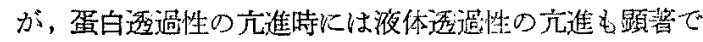
ある事名多い。

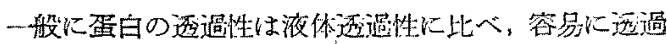
乙難いものである。

2）透過と淔向の起る場仕一致しない，細動・静脈之 毛細血管の機能の差異かと溚えら机る。両名は各々独卉

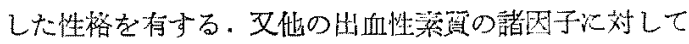

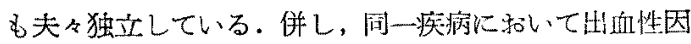

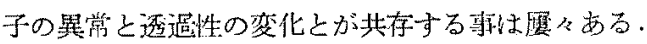

3）所謂掼出性出血のような堨合を除いて，血管の䢙 過性は出血とあまり直接の関保が牦い上うである。

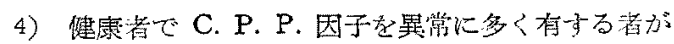
ある.併し同一人に执いても C. P. P. 因于量は常に一 定ではなく，時と共に変動する。

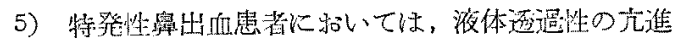
している者が多い．C. P. P. 因子量も，正党者子比較 してや」多量である。

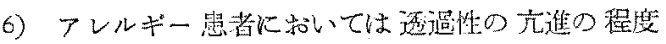

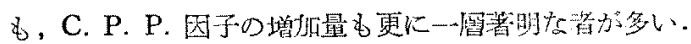

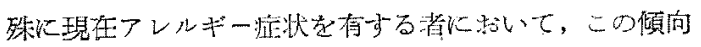
は顕著である。

7）奥出血，咽頭あるいは因肉出血などを起した血小 板減少性紫斑病や白血病のような血液病で当溢血班数梳

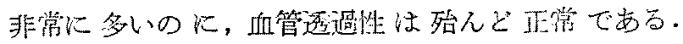
C. P. P. 因子量当健康者と比較して，殆九ど差が見ら れない，2）に述べた通りである。

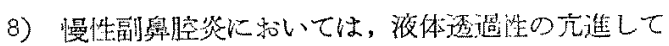

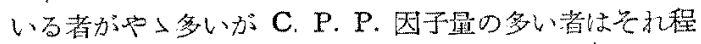
多くない。

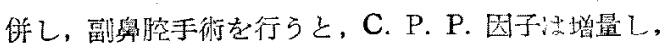
液体远過性。元進する。

9）単なる失血では C. P. P. 因子堅は变動しない寿

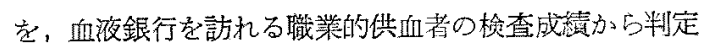
できた。

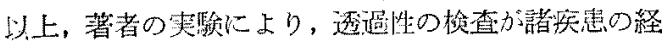
遗中，全身状態定最も面接的飞把握できるという点で注

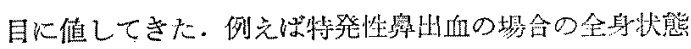
とか、アレルギー性疾患の場合の患名の状態上か在师つ て、これ詨処主る指針を見出寸のに非常に参考にな る.

従らて局所的処置が沿療上余り効果がない上うな埸 合，透過性の異常という背景的な要約を処理する事が， 実地臨床上極るて有効である事が多い，近時各雪の疾患 


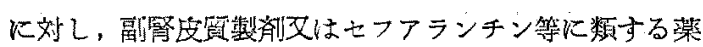
剂の健用が有效且つ適応である場命が多くなりつつある の8当然の㴆結であらう.(セフアランチンの遥過・吸

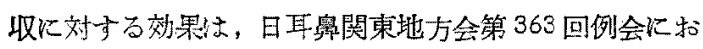
いて発表した)。

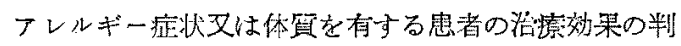

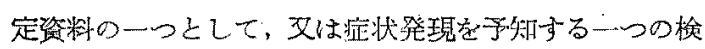

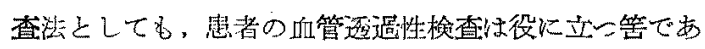
万. 又同時に，逐避性と吸収性とが相㑨つて全身的穖能 と形態が変動するので, 各部位の吸収性も文新しい研究 の対象として，重要な器義を有する事になる。

\section{参考文献}

1) Chamber, R. \& Zweifach, S. R.: Physiological reiews $27: 436$. 2) Cope, O. \& Moore, F.: J. cli. invet $23: 2,1944$. 3) Duran, F.: J. exp. med. 58 : 161, 1933. 4) Duthe, E. S. \& Chain, E.: Brit. J. exp. path. 20: 421, 1939. 5) Eppinger, H.: Verhand. deut. ges. Kreisl. Tag. $11: 166,1938$. 6) Gaddum, J.H.: Brit. med. j. 3. 1948 . 7) Hamble, J. G.: Blood 1: 4, 1949 . 8) Krough, A.: Anatomie und Pathologie der Kapillaren Berlin 1924.

9) Krough, A.: Yale Press 1930. 10) Landis, E. M., Jonas, L., Angevine, M., E Erbr, W.: Physiol. Rev. 14: 404, 1934. 11) Landis, E. M: Physiol. Rev. $14: 404,1934 . \quad$ 12) Lewis, S. T.: The blood vessels of the human skin and their responses London, 1927. 13) Mc. Carrell, J. D.: Amer, J. Physiol, 126:20, 1939. 14) Menkin, V.: J. exp. Med. 67: 145, 1938. 15) Menkin,V.: Arch of Pathol, $41: 1,1946$. 16) Menkin, V.: Arch of Pathol, $41: 4,1946$. 17) Menkin, V.: Newer concepts of Inflammation 1948. 林秀男訳, 炎症の新しい概念, 金原東京, 1954. 18) Ricker, G.: Abderhalden's Handbuch 1:7,509, 1924. 19) Shade, H.: Die physikalishe Chemie Dresden u. Leibzig 1923. 20)
Schmermund, H. J.: Kapillaren und Interstitium 1954. 21) Selye, H.: An international Symposium Monteriol 1953. 22) Spector, W. G.: J. Pathol. and Bact. 63:93,1951. 23) Thoma, R.: Textbook of General Pathologie and Pathological Anathomy London, 328. 24) Unger, G.: Symposium of the Mechanism of Inflammation Monteriol 1953. 25) 天野重安：日病会誌，38：15，1949，26）天野重安：

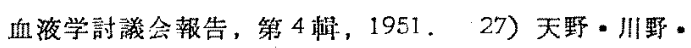
山本安平：日病食誌， $40: 299,1951 ， 28$ ) 天野・川 野・山本：日病会誌，41109，1952。29）平田・中 嚊：医学々生物学，9:51，1946.30) 并上裕司: 日耳率, 59:9,1956.31) 并上裕司: 日耳鬼, 62: 8, 1959.32) 河合貞次: 耳奥臨, 33:9, 1938, 33) 加藤勝治：血液学 討满会報告, 第 4 輤, 1951. 34)

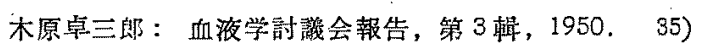

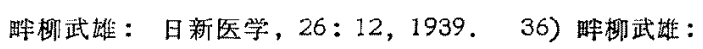
医学の動向，第 13 拏，1957。37)三橋潜：耳酸， 20:3大正 15～昭和 3. 38) 南 - 犬上：日病会誌, $30: 389,1940,39$ ) 西丸和恙: 血液学討議会報告,

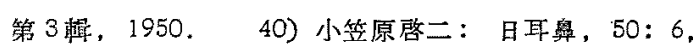
1947.41) 小佐野荻太郎：日耳奥，37：10，42) 千日・乾・松下：日血会誌，12:134，1949。43）千 田信行: 血液学討議会報告, 第 5 輯, 1953. 44) 姝 尾左知丸：最新医学, 13:4,1957,45) 白岩俊雄: 日耳舞，60：臨，1957．46) 白岩俊雄：日耳卑，61:

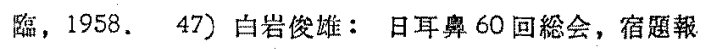
告, 別冊，1959.48）園田四郎：京都府立, 6:5， 49) 渡辺鲃：日耳率，55：10,777，1952。

尚，本論文の要旨は，日耳奥第357回関東地方会, 及び日耳率第 50 回総会に叔いて発表した。

（原稿到着 $=$ 昭和 $35.6: 17$ 日一急载） 